LABORATÓRIO DE VIROLOGIA MOLECULAR PROGRAMA DE PÓS GRADUAÇÃO EM IMUNOLOGIA BÁSICA E APLICADA FACULDADE DE MEDICINA DE RIBEIRÃO PRETO UNIVERSIDADE DE SÃO PAULO

\title{
Avaliação do teste de ELISA in house para Febre Amarela usando o domínio de helicase da proteína NS3 recombinante
}


VITOR GONÇALVES FLORIANO

\title{
Avaliação do teste de ELISA in house para Febre Amarela usando o domínio de helicase da proteína NS3 recombinante
}

\author{
Versão Original
}

Dissertação de Mestrado apresentada ao Programa de PósGraduação em Imunologia Básica e Aplicada para obtenção do Título de Mestre em Ciências.

Área de Concentração: Imunologia Básica e Aplicada.

Orientador: Prof. Dr. Benedito Antonio Lopes da Fonseca

Ribeirão Preto

2020 
Autorizo a reprodução e divulgação total ou parcial deste trabalho, por qualquer meio convencional ou eletrônico, para fins de estudos e pesquisa, desde que citada a fonte.

\section{FICHA CATALOGRÁFICA}

Vitor Gonçalves Floriano

Avaliação do teste de ELISA in house para Febre Amarela usando o domínio de helicase da proteína NS3 recombinante. Vitor Gonçalves Floriano; Orientador, Benedito Antonio Lopes da Fonseca -2020

631 f.: il.; $30 \mathrm{~cm}$

Dissertação (Mestrado em Imunologia) - Programa de Pós-Graduação em Imunologia Básica e Aplicada, Faculdade de Medicina de Ribeirão Preto, Universidade de São Paulo, Ribeirão Preto, 2020.

Versão Original

1 - Arbovírus. 2 - Febre Amarela. 3 - NS3. 4 - Sorologia. 5 - ELISA 
Folha de Aprovação

Nome: Vitor Gonçalves Floriano

Título: Avaliação do teste de ELISA in house para Febre Amarela usando o domínio de helicase da proteína NS3 recombinante

Dissertação apresentada ao curso de Pós-graduação em Imunologia Básica e Aplicada da Faculdade de Medicina de Ribeirão Preto - Universidade de São Paulo, para obtenção de título de Mestre em Ciências.

Aprovado em de de 2020,

\section{Banca Examinadora}

Prof. Dr.

Instituição: Assinatura:

Prof. Dr.

Instituição: Assinatura:

Prof. Dr.

Instituição: Assinatura:

"O presente trabalho foi realizado com apoio da CAPES, Coordenação de Aperfeiçoamento de Pessoal de Nível Superior e ao CNPq, Conselho Nacional de Desenvolvimento Científico e Tecnológico - Brasil”. 
"Se você acender uma lamparina para uma outra pessoa, iluminará também o seu próprio caminho."

Nitiren Daishonin 


\section{AGRADECIMENTOS}

Aos meus pais Sandra Gonçalves Ferreira Floriano e José Roberto Floriano, por todo o apoio, carinho e por sempre batalharem para dar o melhor para mim, apesar das dificuldades, sempre prevalecemos. São minha maior motivação, meus alicerces;

Ao meu orientador, Prof. Dr. Benedito Antonio Lopes da Fonseca pelo incentivo, dedicação e paciência, eu tive a oportunidade de crescer e aprender muito sob sua tutela. Eternamente grato pela sua oportunidade e confiança;

À Dra. Luiza Antunes de Castro Jorge, pela perseverança, paciência e dedicação que teve no auxílio do desenvolvimento deste trabalho. Luiza foi uma pessoa que me apoiou em todos as etapas, não mediu esforços em nenhum momento, é um exemplo de humanidade e profissionalismo. Não tenho palavras para mensurar meu orgulho e gratidão. Você merece toda felicidade do mundo;

Ao Msc. Marcio Junio Siconelli Lima, um grande amigo que apoiou durante este trabalho. Tivemos grandes discussões, trocamos experiências, me auxiliou em praticamente todas as etapas deste estudo. Foi também uma grande válvula de escape para a rotina pesada do nosso trabalho, discutindo sobre vários aspectos da vida, me ajudou a enfrentar vários momentos de frustrações e anseios, és um grande amigo;

Aos meus amigos de laboratório, Taline, Flávia (Flavinha), Beatriz (Bia), Mayara, Jhonatan, Marcus e Danillo que me receberam e me ensinaram boa parte do que sei, parte do meu crescimento se deve a cada um deles;

Aos meus amigos do CPV, Leonardo, Beatriz, Bruna, Suellen, Rosa, Victória, Danilo, Angélica, Ítalo, Marjorie, Andréia e Vinicius que sempre estiveram fazendo parte do meu dia a dia, trazendo alegria, tornando os dias muito mais agradáveis de se viver. Vocês são maravilhosos;

Ao Daniel, quem em muitos momentos me auxiliou no uso de ferramentas de bioinformática. Uma pessoa muito prestativa e complacente, um exemplo de pessoa.

Ao meu amigo Jhefferson Barbosa Guimarães, a quem tenho uma jornada que se estende desde a UFG até a USP, compartilhando bons momentos e agora sendo colega de pós graduação. Um grande amigo;

Aos meus amigos que fiz em Ribeirão Preto, Afonso, Thaianna, Lucas, Felipe, Rodrigo, Emiliano (Fredão), Thais, Maynara, Rafael, Felipe, Carolina e os demais amigos que fiz dentro do programa de Imunologia Básica e Aplicada, gratidão por ter vocês em minha vida;

À Faculdade de Medicina de Ribeirão Preto, da Universidade de São Paulo e ao Programa de Imunologia Básica e Aplicada que me receberam, dando subsídios para construir minha formação. Em especial a Secretária do programa, Ana Cristine;

Ao Conselho Nacional de Pesquisa (CNPq) pelo auxílio financeiro na modalidade de Bolsa de Mestrado e a Coordenação de Aperfeiçoamento Pessoal de Nível Superior (CAPES) 
FLORIANO, V. G. Avaliação do teste de ELISA in house para Febre Amarela usando o domínio de helicase da proteína NS3 recombinante. 2020. 63f. Dissertação (Mestrado). Faculdade de Medicina de Ribeirão Preto - Universidade de São Paulo, Ribeirão Preto, 2020.

\section{Resumo}

A febre amarela é uma arbovirose (vírus transmitido por artrópodes) causada pelo vírus da febre amarela (YFV), que pertence à família Flaviviridae, gênero Flavivirus. O YFV possui dois ciclos de transmissão, um ciclo urbano e um ciclo silvestre, dependendo do vetor responsável pela transmissão viral. Assim como outros flavivírus, o YFV codifica uma poliproteína que é clivada em 3 proteínas estruturais e 7 não estruturais que, apresentam epítopos importantes para a resposta imunológica humoral e celular. A forma mais grave da doença é marcada pela insuficiência de múltiplos órgãos, com predomínio de insuficiência hepática e renal, embora os sistemas nervoso, cardiopulmonar e digestivo também sejam acometidos, este último com sangramento de grandes proporções, o que resulta no "vômito negro". As manifestações clínicas menos graves da febre amarela são comuns a outras infecções por flavivírus, como febre, mialgia, cefaleia, dor retroorbital, etc. Diferentemente das outras infecções por flavivírus, para a prevenção das infecções pelo YFV tem-se a vacina de vírus vivo atenuado (17D/17DD), desenvolvida em 1937e considerada, uma das vacinas mais imunogênicas disponíveis para prevenção de doenças. Entretanto, devido à alta reatividade cruzada do YFV com os vírus da dengue (DENV) e Zika (ZIKV), existe uma necessidade de se fazer o diagnóstico diferencial em relação a estas arboviroses. A NS3 é um proteína não-estrutural do YFV que possui uma das maiores imunogenicidades, comparada a proteína E. Estudos mostram que as proteínas não-estruturais possuem um papel interessante no diagnóstico diferencial de fase aguda de vários vírus. Este estudo buscou explorar o potencial de diagnóstico da NS3, mais especificamente o domínio da helicase, por apresentar a maior imunogenicidade quando comparado ao domínio da protease. O mapeamento de epitopos para reconhecimento de anticorpos mostrou que este domínio possui uma probalidade de $35 \%$ de ser um antígeno para resposta imune humoral. Das amostras testadas, 32/117 foram positivas para IgM pelo ELISA-NS3 $3_{\mathrm{Hel}}$, e 20/117 foram positivas para IgG. Analisando a abordagem diagnóstica para o teste, considerando as amostras PRNT positivas e negativas, o teste mostrou-se ter uma sensibilidade de $29,2 \%$ e uma sensibilidade de $100 \%$, para IgM e para IgG foi observado $26 \%$ de sensibilidade e $100 \%$ de especificidade. Apesar da sensibilidade baixa, o teste foi totalmente especifico para YFV, não reagindo de forma cruzada com amostras de fase aguda de DENV e ZIKV. Porém, devido a positividade de IgM para pacientes vacinados a mais de 1 ano e a baixa positividade para IgG, afere-se que a NS3 3 Hel não seja uma boa escolha para o diagnóstico de YFV, seja para avaliar uma resposta de fase aguda, ou para avaliar a soroconversão decorrente da vacinação e/ou infecção assintomática.

Palavras-chave: Arbovírus, Febre Amarela, NS3, helicase, ELISA 
FLORIANO, V. G. Evaluation of the in-house ELISA test for Yellow Fever using the helicase domain of the recombinant NS3 protein. 2020. 63f. Dissertation (Master's). Ribeirão Preto School of Medicine - University of São Paulo, Ribeirão Preto, 2020.

\begin{abstract}
Yellow fever is an arbovirus (virus transmitted by arthropods) caused by the yellow fever virus (YFV), a virus belonging to the family Flaviviridae, genus Flavivirus, being considered the prototype of this viral family. YFV has two transmission cycles, the urban and the wild cycle, depending on the vector responsible for viral transmission. Like others flaviviruses, YFV's genome consists of a simple strand of positive sense RNA, which encodes a polyprotein that is cleaved into 10 proteins, 3 structural and 7 nonstructural which, depending on the protein, harbor important epitopes for the humoral and cellular immune response. The most serious form of the disease is marked by insufficiency of multiple organs, with predominance of hepatic and renal failure, although the nervous, cardiopulmonary and digestive systems are also affected the latter with major bleeding, which results in "black vomiting". The less serious clinical manifestations of yellow fever are, regardless of the transmission cycle, those common to other infections by flavivirus that is, fever, myalgia, headache, retroorbital pain, etc. Unlike other flavivirus infections, for the prevention of YFV infections we have the live attenuated virus vaccine (17D/17DD), developed in the mid-1930s (last century) and considered, today, one of the most effective vaccines immunogenic drugs available for disease prevention. However, due to the high cross-reactivity between the DENV and ZIKV viruses, as it is a flavivirus, there is a need to make a differential diagnosis in relation to these arboviruses. NS3 is a non-structural protein of YFV that has one of the highest immunogenicity, compared to protein E. Studies show that non-structural proteins have an interesting role in the differential diagnosis of acute phase of several viruses. In this regard, the study sought to explore the diagnostic potential of NS3, more specifically the helicase domain, as it has the highest immunogenicity compared to the protease domain. The mapping of epitopes for antibody recognition, showed that this domain has $35 \%$ potential of being an antigen for humoral immune response. Of the samples tested, 32/117 were positive for IgM by ELISA-NS3 ${ }_{\mathrm{Hel}}$, and 20/117 were positive for IgG. Analyzing the diagnostic approach for the test, considering the positive and negative PRNT samples, the test was shown to have a sensibility of $29.2 \%$ and a specificity of $100 \%$ and for IgG we have sensibility of $26 \%$ and specificity of $100 \%$. Despite the low sensitivity, the test was totally specific for YFV, not cross-reacting with acute phase samples of DENV and ZIKV. However, due to the inconsistency of the data, due to the positivity for IgM of patients vaccinated for more than 1 year and the low positivity for $\mathrm{IgG}$, it appears that $\mathrm{NS}_{3 \mathrm{Hel}}$ is not a reliable protein for the diagnosis of $\mathrm{YFV}$, either to evaluate a response of acute phase, or even seroconversion due to vaccination and/or asymptomatic infection.
\end{abstract}

Keywords: Arbovirus, Yellow Fever, NS3, helicase, ELISA 


\section{Lista de Figuras}

Figura 1: Predições de resposta humoral para as proteínas de YFV .............................25

Figura 2: Análise por BepiPred para a predição de epítopos da NS3 $3_{\mathrm{Hel}}$ para YFV .26

Figura 3: Template da placa de ELISA configurado para testar as amostras clínicas dos pacientes PRNT positivo para YFV .27

Figura 4: Analise da área sob a curva ROC do teste de ELISA para NS3 $3_{\mathrm{Hel}}$ e YFV de acordo com o ensaio de PRNT. .34

Figura 5: Avidez de anticorpos anti-YFV em amostras $\operatorname{IgM}(\mathrm{A})$ e $\operatorname{IgG}(\mathrm{B})$ positivas para o ELISA para $\mathrm{NS}_{\mathrm{Hel}}$. 


\section{Lista de tabelas}

Tabela 1: Sequência nucleotídica do domínio de helicase da NS3 de YFV .22

Tabela 2: Sequência de aminoácidos referente ao domínio de helicase da NS3 de YFV.

Tabela 3: Resultado da probabilidade das proteínas de YFV em induzir uma resposta imune humoral de acordo com sua estrutura linear utilizando a ferramenta BepiPrep .28

Tabela 4: Condições da técnica de ELISA padronizadas utilizando a proteína $\mathrm{NS} 3 \mathrm{Hel}$ .29

Tabela 5: Positividade para o YFV em amostras de pacientes pós-vacinados e PRNT+ utilizando a $\mathrm{NS}_{\mathrm{Hel}}$ e o Vírus da Febre Amarela Selvagem (YFV-WT) como antígeno de captura.

Tabela 6: Positividade para ELISA-NS3 $3_{\text {Hel }}$ e YFV para pacientes PRNT positivo ou negativos que foram vacinados a mais de 1 ano. .26

Tabela 7: Resultado do ELISA dos pacientes com NS1/IgM/IgG e PCR positivos para DENV

Tabela 8: Resultado do teste de ELISA para pacientes que são PCR e/ou PRNT positivos para ZIKV. .28

Tabela 9: Total de amostras positivas e negativas para o teste de ELISA-NS3 ${ }_{\mathrm{Hel}}$ e ELISAYFV. .28

Tabela 10: Positividade para o YFV em amostras de pacientes diagnosticados laboratorialmente com DENV e ZIKV usando a NS3 Hel e YFV para verificar reatividade cruzada.

Tabela 11: Sensibilidade e especificidade para IgM e IgG do ELISA-NS3 $3_{\mathrm{Hel}}$ comparado com os dados de PRNT. .32

Tabela 12: Acurácia, VPP, VPN e Razão de Verossimilhança (RV) do teste de ELISANS3 $3_{\text {Hel }}$ comparado com ELISA-YFV 


\section{Índice}

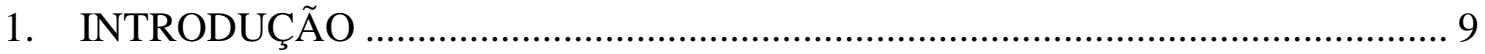

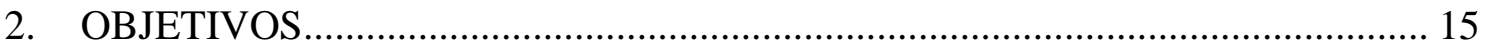

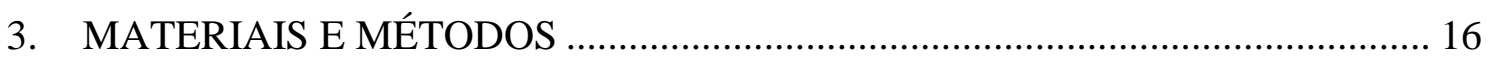

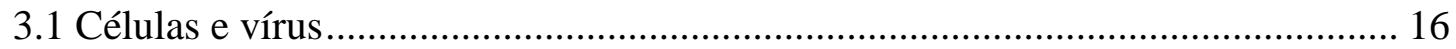

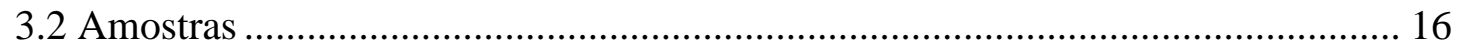

3.3 Seleção e análise das sequências...................................................................... 17

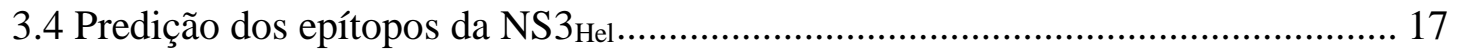

3.5 Obtenção da NS3 Hel recombinante.................................................................... 18

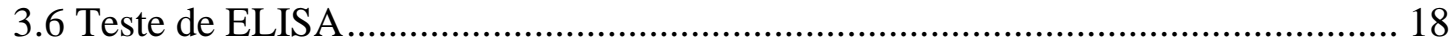

3.7 Teste de Avidez dos anticorpos ....................................................................... 18

3.8 Teste de neutralização por redução de plaques (PRNT) .......................................... 19

3.8 Reatividade cruzada com os vírus DENV-2 e ZIKV ............................................ 20

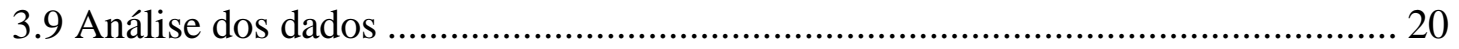

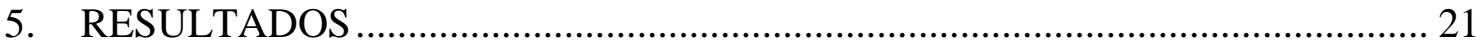

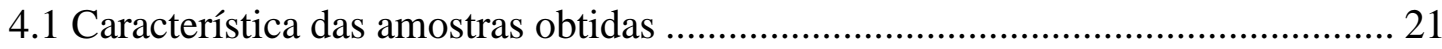

4.2 Estoque do vírus e quantificação por PFU ........................................................... 21

4.3 Seleção da sequência …………………………………………………………... 21

4.4 Obtenção comercial da NS3 Hel...................................................................... 23

4.5 Alinhamento das sequências e predição dos epítopos ............................................ 23

4.6 Padronização do ELISA................................................................................. 27

4.7 Teste com as amostras dos pacientes recém-vacinados e vacinados por longos

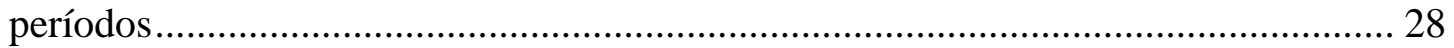

4.8 Reatividade cruzada entre DENV e ZIKV ......................................................... 30

4.9 Ensaio de avidez dos anticorpos anti-YFV vs NS3 Hel ............................................ 34

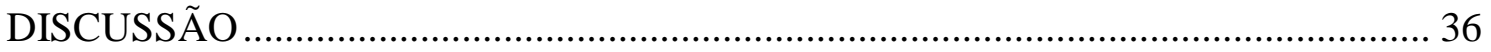

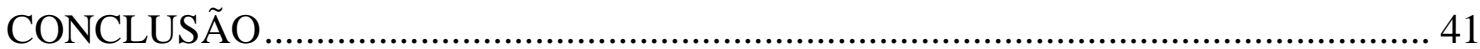

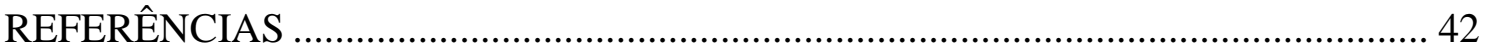

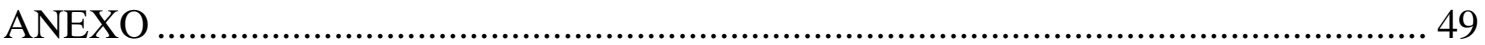




\section{INTRODUÇÃ̃O}

A febre amarela (FA) é uma doença infecciosa, endêmica em regiões tropicais da África e Américas, que apresenta uma grande amplitude de manifestações clínicas, desde apresentações oligossintomáticas até casos extremamente graves, caracterizados por insuficiência de múltiplos órgãos, em particular, insuficiência hepática e renal $(1,2,3)$. A FA é causada pelo vírus da febre amarela (YFV), o arbovírus protótipo do gênero Flavivirus (família Flaviviridae), que possui um genoma composto por uma fita simples de RNA, polaridade positiva e que codifica uma poliproteína composta de três proteínas estruturais e sete proteínas não-estruturais $(4,5,6)$.

As proteínas estruturais (C, E e $p r \mathrm{M})$ formam a estrutura básica da partícula viral e estão associadas a indução da resposta imune humoral(5). Já as proteínas nãoestruturais, NS1, NS2A, NS2B, NS3, NS4A, NS4B E NS5, fazem parte da maquinaria replicativa do vírus, atuando na replicação do RNA e processamento da poliproteína $(4,5)$. Estudos recentes têm demonstrado que as proteínas do envelope (E) e a NS3, possuem os epítopos mais imunogênicos dos flavivírus e têm sido usadas na produção de vacinas recombinantes uma vez que estas proteínas apresentam um papel importante nas respostas humoral e celular, respectivamente $(7,8,9,10,11)$

Quanto aos ciclos de transmissão, nas Américas a FA possui dois ciclos de transmissão bem definidos, o ciclo silvestre e o urbano, sendo que o que diferencia estes dois ciclos sãos os vetores e seus hospedeiros. Independente do ciclo de transmissão, o período de incubação após a picada do mosquito é de aproximadamente 3-6 dias, quando o paciente começa apresentar cefaleia, febre, dores no corpo (mialgias e artralgias) perda de apetite e vômitos. Estes sintomas permanecem por 3-4 dias, quando então há um período de abrandamento ou remissão dos sintomas e o paciente pode se recuperar da doença ou progredir para uma fase mais grave da doença, denominada fase de intoxicação. Progredindo para a forma mais grave da doença, o paciente volta a apresentar febre alta, dor abdominal, diminuição do nível de consciência, náuseas e vômitos, incluindo hematêmese. Ao exame físico, o paciente frequentemente apresenta icterícia e sangramentos de várias fontes (hematêmese, melena, petéquias e equimoses) e progride rapidamente para insuficiência de múltiplos órgãos devido à perda de fluidos e consequente hipotensão, fragilidade capilar, hepatite grave e insuficiência respiratória renal $(1,2,3,5,12,13)$. O diagnóstico diferencial deve ser feito com hepatites virais, dengue grave, malária, leptospirose e outras doenças hemorrágicas. 
A fisiopatologia da doença é multifatorial e inclui efeito citopático viral, necrose e apoptose dos hepatócitos da região midzonal do fígado associada a uma baixa resposta inflamatória, hipoxemia por baixo fluxo e por uma superprodução de citocinas resultante da intensa desregulação do sistema imune(7). A vacinação com a vacina de vírus vivo atenuado (cepa YF-17D) induz, na maioria dos indivíduos vacinados, a ativação de células dendríticas e monócitos, bem como a produção de mediadores próinflamatórios. Anticorpos neutralizantes da classe IgM aparecem de forma rápida e atingem seu pico em aproximadamente 10-14 dias, quando começam a declinar e podem ser detectados por até 6 meses após a infecção/vacinação. Por outro lado, anticorpos neutralizantes da classe IgG são produzidos mais lentamente e podem persistir por longos períodos de tempo, provavelmente por toda a vida, razão pela qual a Organização Mundial da Saúde (OMS) recomenda, como política de saúde pública, apenas uma dose da vacina de vírus atenuado da febre amarela (16).

O diagnóstico sorológico de FA é complicado devido a reatividade cruzada com outros membros do gênero flavivírus (como DENV, WNV, vírus da encefalite de Saint Louis (SLEV) ou ZIKV) (67). Devido a esse fenômeno e a falta de ensaios comerciais amplamente validados, a sorologia muitas vezes acaba sendo superestimada. As infecções por DENV geram um fator de confusão, devido as reações cruzadas nos testes sorológicos comercializados atualmente, e isso é de extrema importância uma vez que DENV e YFV compartilham as áreas de distribuição nas Américas e na África, além de que uma vacina contra o DENV foi recentemente introduzida em alguns países do continente americano $(65,67)$.

A reatividade cruzada de anticorpos a epítopos antigênicos a todos os flavivírus, principalmente na proteína do envelope $(\mathrm{E})$, podem representar um problema importante no diagnóstico sorológico em áreas há circulação $(67,72)$. Esses epítopos compartilhados induzem reação cruzada e também podem levar a um aumento dramático na gravidade de infecções secundárias via mecanismo de ADE, particularmente nos casos envolvendo sorotipos de DENV $(45,79)$.

A OMS estabelece uma abordagem para o diagnóstico sorológico do YFV que difere ligeiramente dependendo do contexto epidemiológico, isto é, situações de surtos versus áreas endêmicas e não-endêmicas (80). Essas diretrizes levam em consideração a presença de vírus que são relacionados antigenicamente, e também a alta prevalência de vacinação em áreas afetadas, onde a implementação concomitante usual de campanhas de vacinação contra o YFV está mais ativa $(2,80)$. 
A OMS recomenda a definição para a suspeita de FA como "qualquer caso que se manifeste com início agudo de febre, com icterícia aparecendo dentro de 14 dias após o início dos primeiros sintomas" (80). Ainda assim, as atribuições correta dos sintomas graves associados a infecção natural e/ou os efeitos adversos da vacinação são particularmente difíceis, considerando em contextos de surtos e/ou epidemias. Onde a semelhança antigênica entre tipo selvagem, da cepa vacinal e o envolvimento de outros flavivírus excluem a identificação sorológica. Atualmente, a distinção só é possível através da caracterização por métodos moleculares, a partir da análise da sequência genômica do vírus $(12,54)$.

Existe uma gama de métodos in-house de sorodiagnóstico de FA, seja para vigilância epidemiológica ou confirmação da resposta imune frente a vacinação. $O$ diagnóstico sorológico é frequentemente solicitado em laboratórios de referência para indivíduos que em algumas circunstâncias especiais tenham comprometimento da resposta à vacinação, exemplo disso inclui-se gestantes, indivíduos sob terapia imunossupressora, HIV+ e ou outros casos de imunodeficiência, seja congênita ou adquirida. O ensaio de neutralização por redução de placa (PRNT) é o método "padrão ouro" para a identificação de anticorpos contra o YFV, e também para os outros flavivírus.

Apesar se ser considerado o "padrão ouro" para a identificação, já foi-se observado um pequeno grau de reatividade cruzada nos ensaios PRNT com outros flavivírus (DENV e ZIKV, principalmente). No entanto, o PRNT, possui a maior especificidade do que outros ensaios, chegando a mais que $90 \%$ de especificidade (embora a sensibilidade possa diminuir quando considerado os aspectos citados acima). Contudo, para os ensaios PRNT, a execução requer instalações apropriadas para manter o cultivo de células, disponibilidade de controles muito bem padronizados e equipe capacitada para obter resultados reprodutíveis. Esta é uma situação limitante para muitos laboratórios de referência, o que pode dificultar a obtenção do diagnóstico em situações de epidemias. Além disso, o tempo para a interpretação dos resultados, que geralmente é em torno de 4 a 7 dias, atrasa o diagnóstico, o que não é adequado para a tomada de decisões durante uma resposta a epidemias, principalmente quando se analisa a respeito da implantação da políticas de vacinação nesse contexto.

Atualmente, o procedimento de diagnóstico laboratorial mais difundido consiste na detecção de anticorpos anti-YFV por meio da técnica de ELISA. O teste é realizado em poucas horas e fornece um diagnóstico presuntivo da infecção pelo vírus. 
Ainda nesse procedimento existe uma limitação que é a reatividade cruzada já conhecida. Sabe-se que em regiões endêmicas, a imunidade contra outros flavivírus acaba se tornando generalizada. Além disso, pacientes com febre hemorrágica e com choque causados pelo DENV apresentam um quadro clínico semelhante ao YFV. Outro fator limitante é que a produção de anticorpos, principalmente anticorpos da classe $\operatorname{IgM}$, que podem estar em baixos títulos durante infecções secundárias. Um fato é que, durante infecções secundárias, a IgM é produzida apenas nos primeiros dias (entre $2^{\circ}$ e o $3^{\circ}$ dia) e em títulos muito baixos, algumas vezes no limiar de detecção (corte) do IgM-ELISA. Em contraparte, existem relatos de que, após infecções por YFV, a IgM pode persistir por longos períodos, até por mais de um ano, sendo considerado, até então, um marcador não confiável de uma infecção recente por YF.

Os métodos de diagnóstico sorológicos baseados na detecção de anticorpos para as proteínas não-estruturais (NSP) vem ganhando espaço para os testes de escolha na detecção de infecção por vários arbovírus. Os ensaios de detecção de anticorpos para as NSP tem fornecendo uma contribuição crítica para a análise de risco e avaliação de impacto dos programas de controle de várias doenças, uma vez que a variabilidade no início, na especificidade e na duração da resposta humoral, durante a infecção, é limitada, quando se trata dessas estruturas, sendo considerada por vários estudos uma forma alternativa de desenvolver um ensaio para o diagnóstico diferencial $(16,17)$.

As proteínas não estruturais, NS1, NS2, NS3, NS4 e NS5 codificadas pelo genoma do YFV, estão envolvidas na replicação, maturação e exportação dos virions nas células infectadas e apresentam uma potente imunogenicidade (sabidamente maior para resposta imune celular em relação a humoral). A NS3, é sintetizada em grandes quantidades nas células de insetos, e está sendo considerada uma possível candidata para o desenvolvimento de teste diagnóstico, pois além de ser produzida em grandes quantidades, possui propriedades imunológicas de extrema importância, sendo considerada equivalente a proteína $\mathrm{E}$, que é considerada a mais imunogênica do vírus da Febre Amarela.

A proteína NS3 abrange em torno de 1027-1659 aminoácidos, possui um peso de aproximadamente $69 \mathrm{kDa}$. Ela possui duas funções principais, a primeira consiste numa atividade de serino-protease na porção N-terminal e a segunda função de helicase na porção C-terminal, tendo uma importância crítica na replicação viral, sendo alvo que vem ganhando destaque na pesquisa, tanto para teste diagnóstico quanto para tratamento de muitos flavívirus. A proteína NS3 do YFV, aparece, principalmente, em infecções 
primárias e, no início da infecção, os níveis são sustentados pelo tempo em que o vírus permanece replicando, ou seja, durante a fase aguda. Além disso, sua forte afinidade com anticorpos tanto da classe $\operatorname{IgM}$ quanto IgG sugere uma maior vantagem em laboratório para detecção.

Um estudo conduzido por Robert et al. (2002) identificou epítopos do YFV responsáveis por estimular resposta imune celular. No estudo, como fonte de estimulação antigênica, usaram células infectadas por YFV, e um conjunto de peptídeos que se sobrepõem regiões das proteínas E, PrM e a NS3. A sobreposição dos peptídeos permitiu encontrar epítopos restritos ao MHC classe I e classe II, independentemente de alelos específicos. Esta estratégia de mapeamento de epítopos foi usada com sucesso e foi possível mapear os epítopos restritos as células TCD8 e TCD4, mostrando que a NS3 e a proteína E eram os que possuíam a maior imunogenicidade. Essa abordagem permitiu dar os primeiros passos para averiguar a passividade dessas proteínas serem candidatas para desenvolvimento de vacinas e testes diagnósticos.

Outros estudos exploraram o potencial terapêutico e de diagnóstico das proteínas não estruturais dos arbovirus, incluindo a NS3. Um trabalho publicado por Rosa et al. (2014) mostrou a imunogenicidade da proteína NS3 do DENV (DENV2-NS3), produzida por clonagem molecular, em camundongos BALB/c. No estudo, foi determinada a reatividade antigênica da proteína NS3 recombinante contra um painel de anticorpos murinos de todos os quatro sorotipos, bem como, avaliando o perfil de secreção de citocinas de células do baço dos camundongos infectados com DENV-2, onde essas células foram estimuladas in vitro pela NS3 recombinante. Foi demonstrado que a proteína NS3 purificada preservou a integridade antigênica da proteína nativa viral e induziu a produção de altos títulos de anticorpos anti-NS3 recombinante.

Um outro estudo, coordenado por Narayan et al. (2016), desenvolveu um ELISA indireto baseado na proteína não estrutural 5 (NS5) do sorotipo 2 do vírus da dengue (DENV2). Neste estudo, a NS5 foi usada para explorar seu potencial diagnóstico como uma alternativa aos ELISA da proteína E, M e NS1 que atualmente são usadas como antígenos de captura. Verificou-se, ainda nesse estudo que o ensaio era possuía $100 \%$ de especificidade na detecção de anticorpos para DENV2 nos soros dos pacientes infectados. No entanto, em termos de sensibilidade, o ensaio só conseguiu detectar anticorpos $\operatorname{IgM}$, onde cerca de $90 \%$ das amostras foram positivas. Os resultados mostraram que o ELISA desenvolvido era específico nos grupos positivos para dengue e 
poderia ser usado para diagnóstico diferencial de dengue em relação as outras infecções por flavivírus que circulavam naquela região.

Estratégias para o desenvolvimento de testes de diagnóstico diferenciais para arboviroses é de suma importância para aumentar a eficiência do resultado, principalmente aumentando a especificidade, pois a grande maioria das viroses do nosso país tem como principais agentes etiológico vírus da família Flaviviridae, isto ressalva a importância do diferencial para evitar reações cruzadas entre os vírus desta mesma família evitando um diagnóstico equivocado. 


\section{OBJETIVOS}

\section{Objetivo geral}

O objetivo deste estudo foi avaliar o potencial do domínio de helicase da proteína não estrutural $3\left(\mathrm{NS}_{\mathrm{Hel}}\right)$ no diagnóstico sorológico do vírus da Febre Amarela, visando o desenvolvimento de um ensaio imunoenzimático in house no diagnóstico diferencial em relação aos DENV e ZIKV.

\section{Objetivos específicos}

1. Selecionar a sequência correspondente a região da $N S 3_{\text {Hel }}$ para a obtenção comercial da mesma;

2. Fazer análise de predição da imunogenicidade do domínio de helicase da NS3 do YFV, assim como das demais regiões da poliproteina;

3. Avaliar o potencial de $\mathrm{NS} 3_{\text {Hel }}$ para a captura de anticorpos da classe $\operatorname{IgM}$ e $\operatorname{IgG}$, por meio da técnica de ELISA;

4. Avaliar a sensibilidade e especificidade do ELISA in house em relação ao PRNT;

5. Avaliar a avidez dos anticorpos IgM e IgG nas amostras positivas para o ELISA; 


\section{MATERIAIS E MÉTODOS}

\subsection{Células e vírus}

Estoques da cepa YFV (JabSPM02 - Faculdade de Medicina, Departamento de Clínica Médica, Ribeirão Preto, São Paulo, Brasil) (41), foram preparadas em células Vero (uma linhagem de células estabelecida a partir de células renais de macaco verde africano [Cercopithecus aethiops]) e usados durante todos os experimentos laboratoriais. Células Vero foram mantidas a $37^{\circ} \mathrm{C}$ em meio de cultura Dulbecco's Modified Eagle Medium (DMEM) contendo 10\% de soro fetal bovino (DMEM-10\% FBS), 150UI/mL de estreptomicina/penicilina/antimicótico. As células Vero foram infectadas com os vírus (17DD; DENV-2 e ZIKA) durante 1 hora à temperatura ambiente e após retirar o inóculo, um meio de manutenção (DMEM-2\%FBS) foi adicionado à cultura de célula e incubadas a $37^{\circ} \mathrm{C}$. Sobrenadantes de células Vero infectados com os vírus foram coletados, centrifugados para a remoção de debris celulares, aliquotados na presença de DMEM$20 \% \mathrm{FBS}$ e armazenados a $-80^{\circ} \mathrm{C}$ para uso posterior. Os títulos virais dos estoques foram determinados por PFU.

\subsection{Amostras}

As amostras de soros foram adquiridas a partir de coletas realizadas no HCFMRP. Para o teste, foram definidos 4 grupos de amostras para validação, totalizando 117 amostras, sendo:

1. O primeiro grupo, consistiu em 38 amostras de pacientes que receberam a vacina 17DD e foram acompanhados por um período de 180 dias. A triagem baseou-se em obtenção das amostras do dia 7, 30, 90 e 180 dias pós-vacinação. Para cada dia obteve-se:

- 7 dias: 8 amostras;

- 30 dias: 10 amostras;

- 90 dias: 10 amostras;

- 180 dias: 10 amostras;

Devido a desistência de alguns indivíduos, não foi possível obter a amostra sequencial do mesmo paciente. 
2. O segundo grupo, consistiu em 21 pacientes de fase aguda para DENV, as amostras foram confirmadas para NS1, IgM e/ou IgG e algumas foram PCR positivas;

3. Já o terceiro grupo, consistiu em 10 pacientes de fase aguda para ZIKV que foram positivos para PRNT e PCR.

4. Por fim, o quarto grupo correspondeu a 48 amostras de pacientes, que foram PRNT+ ou PRNT- para YFV, para validação do teste.

Todos os pacientes tiveram acesso ao termo de consentimento livre e esclarecido, e a pesquisa foi aprovada pelo Comitê Nacional de Ética e Pesquisa de acordo com a Resolução 466/12 do Conselho Nacional de Saúde, bem como suas complementares tendo como registro da CAAE o número 974167118.8.0000.5440 e o Número do Certificado de Apresentação para Apreciação Ética é o 2.914.563.

\subsection{Seleção e análise das sequências}

A sequência da $\mathrm{NS}_{\text {Hel }}$ de YFV foi obtida a partir da sua sequência genômica da cepa YFU17066 (Departamento de Bioquímica e Biologia Molecular, FIOCRUZ, Rio de Janeiro, RJ, Brasil) disponível sob o código: AAC54267 no Gene Bank (NCBI) (87). A sequência está localizada entre os nucleotídeos 5101 e 6421 do genoma viral. A região corresponde a um fragmento que engloba desde o final do domínio de protease da NS3 até o final do domínio de helicase, de todos os vírus. A fim de verificar a semelhança das sequencias das cepas utilizadas neste projeto, foi realizado o alinhamento comparando a sequência da NS3 $3_{\text {Hel, }}$ utilizando o software CLC Sequence Viewer (Qiagen).

\subsection{Predição dos epítopos da NS3Hel}

Para a análise de epítopos da NS3 $3_{\text {Hel }}$ no intuito de verificar a imunogenicidade mediante ao reconhecimento de anticorpos, foi utilizado a ferramenta B Cell Epitope Prediction (Bepipred) da Immune Epitope Database (IEDB)(http://tools.iedb.org/main/), que consiste num banco de dados do Instituto Nacional de Alergia e Doenças Infecciosas (NIAID) para predição e análise de epítopos para peptídeos contínuos, a analise se baseia nas características físico-químicas entre os aminoácidos. As sequências de nucleotídeos da cepa YFU17066 foram traduzidas em uma sequência linear aminoácidos e submetidas para análise. As analises foram feitas tanto para a NS3Hel, quanto para as proteínas 
estruturais (E, M e Capsídeo) e as demais não estruturais (NS1, NS2, NS3 completa e domínio de protease, NS4 e NS5).

\subsection{Obtenção da NS3Hel recombinante}

A NS3 3 Hel foi obtida de forma comercial pela GenScript LTDA. Todas as etapas de produção da proteína recombinante foi realizada pela empresa, desde a síntese gênica, otimização de códons e refolding de proteína.

\subsection{Teste de ELISA}

Para o teste de ELISA, cada uma das amostras de soro foi testada para anticorpos contra $\mathrm{NS}_{\text {Hel }}$ e YFV. As placas de 96 poços foram revestidas overnight a $4{ }^{\circ} \mathrm{C}$ com 40 ng NS3 3 Hel (essa quantidade foi determinada previamente). No dia seguinte, cada poço foi lavado 4x com solução PBS-T e depois bloqueado por 1 horas a $37{ }^{\circ} \mathrm{C}$ com $200 \mu \mathrm{L}$ de tampão de bloqueio contendo $1 \%$ de leite em pó desnatado (LPD). Após a incubação, as placas foram lavadas 3x com PBS 1x 0,2\% Tween 20 (PBS-T). Em seguida, foi feita diluição dos soros em PBS 1x c/ 1\% LPD numa diluição de 1:100. Os soros diluídos foram adicionados à placa e incubados por 1 hora a $37^{\circ} \mathrm{C}$. Após a incubação as placas foram lavadas 3x com PBS-T, em seguida, foi adicionado $100 \mu \mathrm{L}$ do anticorpo secundário conjugado com peroxidade (HRP). Para anti-IgM-HRP, diluiu-se 1:5000 em PBS 1x 1\% LPD, enquanto que para anti-IgG-HRP, diluiu-se 1:10000 em PBS 1x 1\% LPD, seguido da incubação por mais 2 horas a $37{ }^{\circ} \mathrm{C}$. Posteriormente, lavou-se $4 \mathrm{x}$ com PBS-T, foi adicionado $100 \mu \mathrm{L}$ de substrato TMB seguido da incubação da placa por 15 minutos em câmara escura. Por fim, após a reação enzimática, adicionou-se $100 \mu \mathrm{L}$ de solução $\mathrm{HCl}$ $1 \mathrm{M}$ (stop solution) para inibição da reação. A leitura da absorbância foi medida a 450/620 $\mathrm{nm}$ em um espectrofotômetro de microplaca Epoch.

\subsection{Teste de Avidez dos anticorpos}

Para determinar a avidez entre os anticorpos da classe IgM e IgG nas amostras dos pacientes com a proteína recombinante, realizou-se o ensaio de avidez, descrito por Levett et al. Nesse procedimento, seguiu-se exatamente o protocolo de ELISA, porém, após a incubação com o anticorpo primário (amostras de camundongos e/ou de humanos positivas para YFV), adicionou-se 100 ul de solução de ureia a 6M em PBS-1X ou apenas 
PBS-1X e incubou-se por 10 minutos a $37^{\circ} \mathrm{C}$ em câmara úmida. Após isso, lavou-se os orifícios por 3 vezes com PBS-T e seguiram-se as etapas do ensaio de ELISA. Ao final, calculou-se o Índice Relativo de Avidez (IRA). O cálculo é feito dividindo o valor da D.O dos poços tratados com a solução de ureia pelos poços não tratados com ureia, em seguida multiplica-se o valor obtido por 100, dando o resultado em porcentagem. O IRA, expressa a reatividade remanescente após o tratamento com a ureia, onde a solução é utilizada para romper as ligações fracas entre os anticorpos e a proteína recombinante. Amostras com IRA superior ou igual a $50 \%$ foram denominadas de alta avidez, enquanto que aquelas entre $30-49 \%$ foram consideradas de média avidez e as IRA inferior a $30 \%$ são consideradas de baixa avidez (81).

$\operatorname{IRA}(\%)=$ D.O das amostras tratadas com ureia / D.O das amostras não tratadas com ureia

\subsection{Teste de neutralização por redução de plaques (PRNT)}

O título de anticorpos neutralizantes contra o YFV foi realizado pelo PRNT (36) e já padronizado em nosso laboratório. Este teste foi realizado em amostras de soro dos pacientes, sendo catalogadas, centrifugadas para separação do soro, aquecidas para inativação do sistema complemento e diluídas 1:10 a partir da diluição. Um volume de $250 \mu \mathrm{L}$ das diluições da amostras e de estoque viral [contendo 50 PFU da cepa JabSPM02 (adaptados à cultura de célula) em $250 \mu \mathrm{L}$ ] foram misturadas e incubadas por 1 hora a $37^{\circ} \mathrm{C}$ e, então, $200 \mu \mathrm{L}$ desta mistura adicionados a placas de cultura de 24 poços de fundo chato contendo monocamadas confluentes de células Vero. Amostras de soro, positivas e negativas para anticorpos neutralizantes contra o 17DD previamente calibradas em nosso laboratório foram incluídas em cada teste. Após a infecção das células Vero com a mistura amostra/vírus por uma hora a $37^{\circ} \mathrm{C}$ com agitação leve a cada 10 minutos, o inóculo foi removido cuidadosamente por pipetagem (da amostra mais diluída para a menos diluída) e um meio semi-sólido de carboximetilcelulose (CMC) a 2\% de SBF foi colocado em cada poço e as placas incubadas por 7 dias em incubadoras a $37^{\circ} \mathrm{C}$ e $5 \% \mathrm{CO}^{2}$, quando então o meio semi-sólido foi retirado e a monocamada levada e fixada com $0,2 \mathrm{~mL}$ de formaldeído (10\%) por 1 hora. O formaldeído foi descartado, as monocamadas lavadas e coradas com $200 \mu \mathrm{L}$ de cristal violeta, sendo o título de anticorpos neutralizante 
determinado pela diluição da amostra (em comparação com os soros padrão) que reduziu o número de placas em relação ao controle do vírus selvagem.

\subsection{Reatividade cruzada com os vírus DENV e ZIKV}

A fim de verificar a reatividade cruzada da $\mathrm{NS}_{\text {Hel }}$ com DENV e ZIKV, aplicouse o ELISA para amostras humanas sorologicamente positivas para os vírus citados. As amostras tentadas para DENV foram amostras positivas por testes imunocromatrográficos Dengue DUO (Alere) para NS1, IgM e/ou IgG e por métodos moleculares, aplicando a técnica de RT-qPCR. Já as amostras testadas para ZIKV, corresponde a soros que foram RT-qPCR e PRNT50 positivas para o mesmo. Durante a triagem, foi dado preferência para amostras de fase aguda das infecções, onde a chance de possuir reatividade cruzada é mais elevada.

\subsection{Análise dos dados}

O cálculo do ponto de corte (cut-off) para o teste de ELISA foi realizado com base na média das densidades óticas (D.O) obtidas em 4 orifícios contendo soro negativo para todos os vírus e acrescentado 3 desvios-padrão. Portanto, valores acima do cut-off foram considerados reagentes, enquanto os valores abaixo do cut-off foram considerados não reagentes.

Já a abordagem diagnóstica referente ao teste, foi calculada baseada na ferramenta disponibilizada pela Biblioteca Virtual em Saúde (BSV) visando determinar a sensibilidade, especificidade, acurácia, valor preditivo positivo (VPP), valor preditivo negativo (VPN) e razão de verossimilhança para teste positivo (likelihood ratio) (https://aps.bvs.br/apps/calculadoras/?page=1). Adicionalmente, os dados de avidez e curva ROC foram analisados no programa Graphpad Prism vs8. 


\section{RESULTADOS}

\subsection{Característica das amostras obtidas}

Durante a triagem das amostras obtivemos um total de 104 amostras positivas para o PRNT para YFV e 13 negativas para o PRNT. Aa faixa etária média foi de 31,4 anos de idade, com $60 \%$ das amostras pertencentes a pacientes do sexo masculino e $40 \%$ do sexo feminino

Tabela 1. Características epidemiológicas dos pacientes segundo a confirmação laboratorial do PRNT

\begin{tabular}{rc|c|c}
\hline & PRNT+ & PRNT- & Total \\
\cline { 2 - 3 } Idade (em anos) & $34( \pm 46)$ & $29( \pm 34)$ & \\
\hline Sexo masculino & 64 & 6 & 70 \\
\hline Sexo feminino & 40 & 7 & 47 \\
\hline
\end{tabular}

\subsection{Estoque do vírus e quantificação por PFU}

O estoque do YFV foi produzido com base numa cepa recém isolada em nosso laboratório. Por meio da titulação em células VERO foi determinado que este estoque viral apresentou uma concentração de $1 \times 10^{6} \mathrm{PFU} / \mathrm{mL}$. Este estoque foi utilizado na sensibilização da placa de ELISA para comparação com o peptídeo de NS3 $3_{\text {Hel. }}$

\subsection{Seleção da sequência}

A sequência núcleotídica da proteína $\mathrm{NS}_{\text {Hel }}$ utilizada pertence ao vírus vacinal 17DD (Bio-manguinhos).

Tabela 2. Sequência nucleotídica do domínio de helicase da NS3 de YFV

\begin{tabular}{|l|l|}
\hline \multicolumn{1}{|c|}{ Região } & \multicolumn{1}{c|}{ Sequência Nucleotídica } \\
\hline Domínio de helicase & GAACTACGCGAGATTCCGACCATGCTGAAGAA \\
$($ NS3 $)$ & GGGTATGACCACCATCCTGGATTTTCACCCGGG \\
$(1209 \mathrm{pb})$ & TGCGGGCAAGACCCGTCGTTTTCTGCCGCAGAT \\
\hline
\end{tabular}




\begin{tabular}{|l|l|}
\hline CCTGGTTCTGGCGCCGACCCGTGTGGTTCTGAG \\
CGAGATGAAGGAAGCGTTCCACGGTCTGGACG \\
TTAATTCCACACCCAAGCGTTTAGCGCGCATG \\
GTAGCGGTCGTGAGGTGATCGATGCGATGTGCC \\
ACGCGACCCTGACCTATCGTATGCTGGAACCGA \\
CCCGTGTGGTTAACTGGGAAGTGATCATTATGG \\
ACGAAGCGCACTTTCTGGATCCGGCGAGCATTG \\
CGGCGCGTGGCTGGGCGGCGCACCGTGCGCGT \\
GCGAACGAGAGCGCGACCATTCTGATGACCGC \\
GACCCCGCCGGGTACCAGCGATGAATTCCCGCA \\
CAGCAACGGCGAGATCGAAGACGTTCAGACCG \\
ATATTCCGAGCGAGCCGTGGAACACCGGTCAC \\
GACTGGATCCTGGCGGATAAGCGTCCGACCGC \\
GTGGTTTCTGCCGAGCATTCGTGCGGCGAACGT \\
GATGGCGGCGAGCCTGCGTAAGGCGGGCAAAA \\
GCGTGGTTGTCTGAACCGTAAGACCTTCGAGC \\
GTGAATATCCGACCATCAAACAGAAGAAACCG \\
GACTTTATCCTGGCGACCGATATTGCGGAGATG \\
GGTGCGAACCTGTGCGTTGAACGTGTGCTGGAC \\
TGCCGTACCGCGTTCAAACCGGTTCTGGTGGAT \\
GAAGGTCGTAAGGTTGCGATCAAAGGTCCGCT \\
GCGTATTAGCGCGAGCAGCGCGGCGCAACGTC \\
GTGGTCGTATTGGCCGTAACCCGAACCGTGACG \\
GTGATAGCTACTATTACAGCGAGCCGACCAGCG \\
AAAACAACGCGCACCATGTGTGCTGGCTGGAG \\
GCGAGCATGCTGCTGGACAACATGGAAGTTCGT \\
GGTGGCATGGTGGCGCCGCTGTACGGTGTGAA \\
GGTACCAAGACCCCGGTGAGCCCGGGTGAAAT \\
GCGTCTGCGTGACGATCAACGTAAAGTTTTCG \\
TGAACTGGTGCGTAACTGCGACCTGCCGGTTG \\
GCTGAGCTGGCAAGTGGCGAAAGCGGGCCTGA \\
AGACCAACGAC \\
\hline
\end{tabular}

Esse domínio codifica uma proteína de 398 aminoácidos, com um peso molecular de aproximadamente $45 \mathrm{kDw}$.

Tabela 3. Sequência de aminoácidos referente ao domínio de helicase da NS3 de YFV

\begin{tabular}{l|l}
\hline Região & Sequência de aminoácidos \\
\hline NS3 $_{\text {Hel }}$ & ELREIPTMLKKGMTTILDFHPGAGKTRRFLPQILAECARRRLRTLVL \\
& APTRVVLSEMKEAFHGLDVKFHTQAFSAHGSGREVIDAMCHATLT \\
& YRMLEPTRVVNWEVIIMDEAHFLDPASIAARGWAAHRARANESAT \\
& ILMTATPPGTSDEFPHSNGEIEDVQTDIPSEPWNTGHDWILADKRPT \\
& AWFLPSIRAANVMAASLRKAGKSVVVLNRKTFEREYPTIKQKKPDF \\
& ILATDIAEMGANLCVERVLDCRTAFKPVLVDEGRKVAIKGPLRISAS \\
& SAAQRRGRIGRNPNRDGDSYYYSEPTSENNAHHVCWLEASMLLDN \\
& MEVRGGMVAPLYGVEGTKTPVSPGEMRLRDDQRKVFRELVRNCD \\
& LPVWLSWQVAKAGLKTND \\
\cline { 2 - 2 }
\end{tabular}




\subsection{Obtenção comercial da NS3Hel}

De acordo com o certificado de analise (Anexo A) a proteína foi expressa em sua forma insolúvel. O sistema de expressão e o vetor utilizados foram $E$. coli e o vetor pET30a, respectivamente. A proteína foi obtida numa concentração de $0,27 \mathrm{mg} / \mathrm{mL}$, com $90 \%$ de pureza e o nível de endotoxina permuta em torno de $7.3 \mathrm{UE} / \mathrm{mg}$. O recombinante foi ressuspendido em solução PBS contendo $10 \%$ de glicerol, 0.5 M L-Arginina em pH 7.4. Todos os resultados detalhados referente a produção da proteína recombinante estão em anexo.

\subsection{Alinhamento das sequências e predição dos epítopos}

Foram selecionadas as sequências referentes ao domínio da helicase dos vírus YFV7DD, ZIKV e DENV-2. As sequências selecionadas foram correspondentes a cepa que usamos de referência no nosso laboratório. Os anexos B e C mostram o resultado do alinhamento das sequências de nucleotídeos do domínio da helicase da NS3 dos 3 vírus. A similaridade entre a sequencia nucleotidica de YFV com DENV-2 corresponde a $51,3 \%$, e, entre YFV e ZIKV corresponde a 51,5\%. O alinhamento dos nucleotídeos teve como objetivo mostrar que as sequência da NS3 Hel dos flavivirus selecionados, por mais que tenham a mesma função biológica e, talvez, tenham imunogenicidade semelhante, são diferentes entre os vírus. Além do mais, é sabido que a NS3 e a NS5 são as proteínas mais conservadas entre os flavivírus, reflexo de sua importância na replicação, uma vez que qualquer mutação pode comprometer a a produção de novos virions (76).

Após esta análise, as sequências de aminoácidos, referentes a tradução as sequência de aminoacidos, foram submetidas a predições de epítopos. As predições foram realizadas pela ferramenta do IEDB, que baseia-se na análise de diversos parâmetros como hidrofobicidade, flexibilidade da proteína, acessibilidade, curvas, exposição de superfície, polaridade e propensão antigênica de cadeias polipeptídicas. Essa análise, mais especificamente, está correlacionada com epítopos contínuos ou também chamados de lineares. Dessa forma, a ferramenta pode prever a posição de epítopos a partir de certas características da sequência proteica. Para a sequência proteica, optou-se por fazer para a NS3 e as demais proteínas do YVF (proteína E, C, PrM, NS1, NS2, NS4 e NS5).

Os cálculos de previsão são baseados em escalas de propensão para cada um dos 20 aminoácidos existentes. Cada escala consiste em 20 valores atribuídos a cada um dos 
resíduos de aminoácidos com base em sua propensão relativa em possuir as propriedades descritas acima. A figura 1, mostra o gráfico feito a partir da análise das sequências de todas as proteínas do YFV.
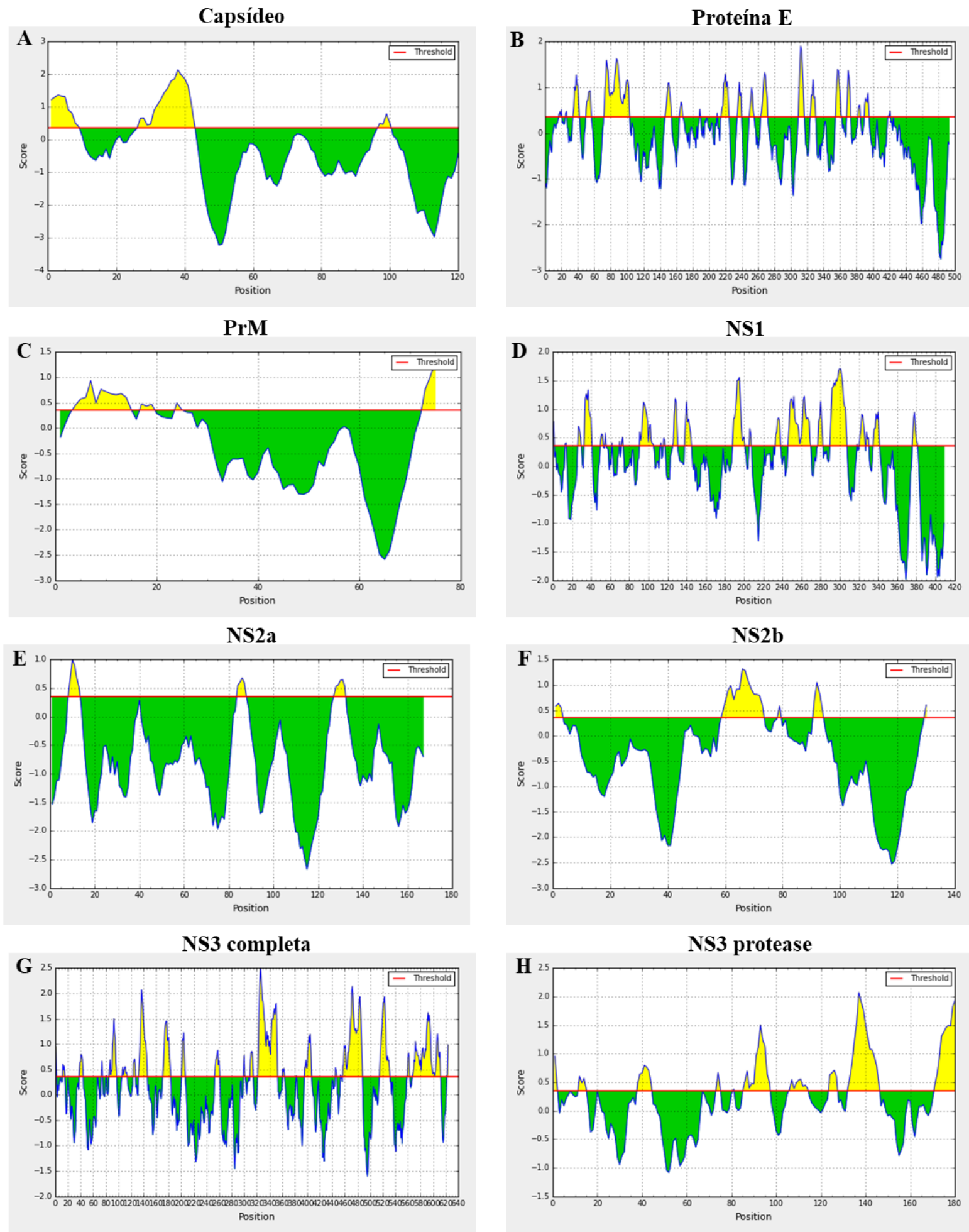

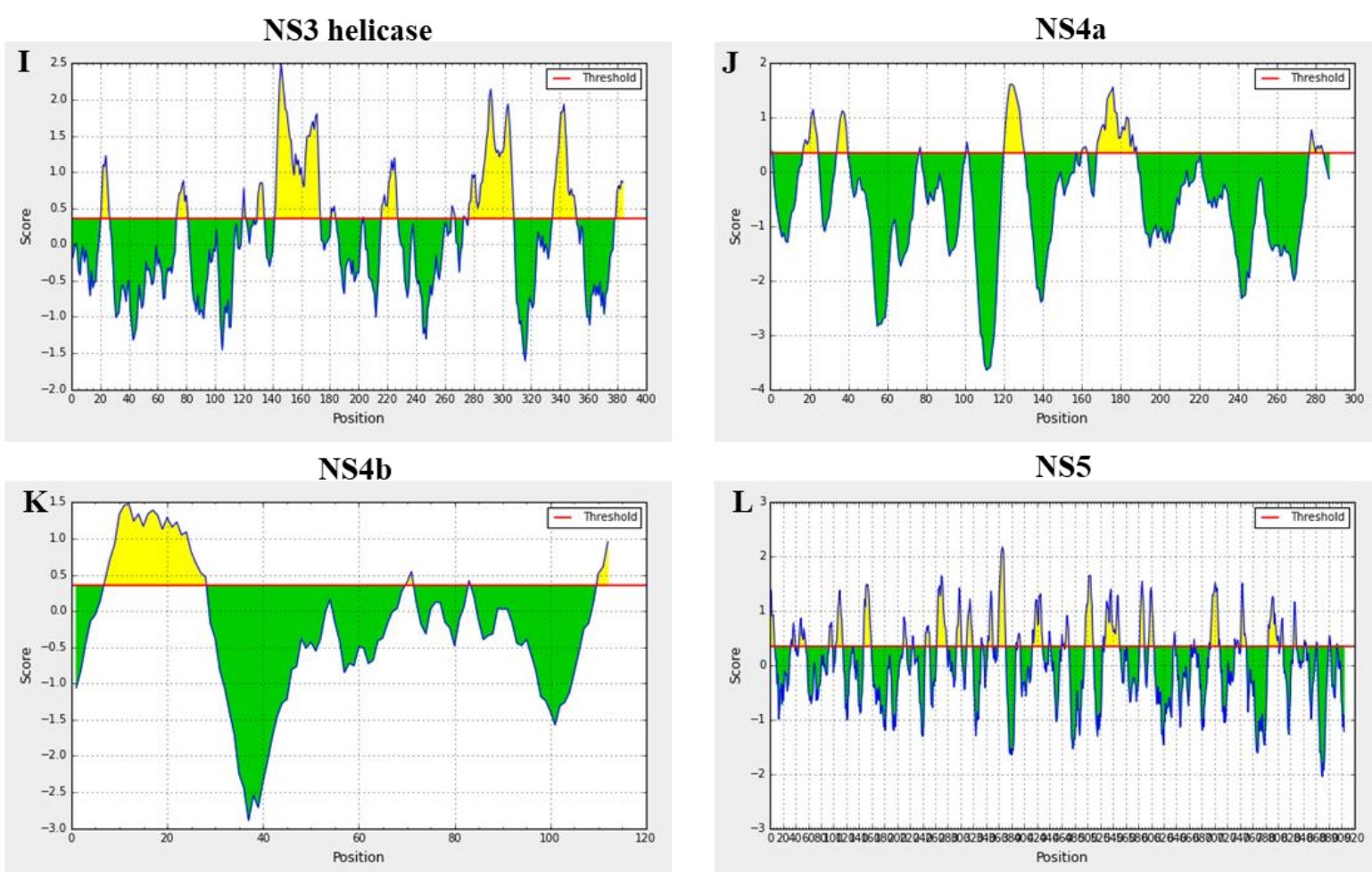

Figura 1: Predições de resposta humoral para as proteínas de YFV. A: Capsídeo; B: Proteína E; C: PrM; D: NS2; E: NS2a; F: NS2b; G: NS3; H: NS3Pro; I: NS3Hel; J: NS4a e K: NS4b e L: NS5

A relação geral do score de imunogenicidade para as demais proteínas estão descritos na tabela 3 .

Tabela 3. Resultado da probabilidade das proteínas de YFV em induzir uma resposta imune humoral de acordo com sua estrutura linear utilizando a ferramenta BepiPrep

\begin{tabular}{ccc}
\hline Proteína & $\begin{array}{c}\text { Probabilidade de ser } \\
\text { antígeno }\end{array}$ & $\begin{array}{c}\mathbf{N}^{\mathbf{0}} \text { de } \\
\text { resíduos }\end{array}$ \\
\hline Capsídeo & $25 \%$ & 3 \\
\hline PrM & $22 \%$ & 3 \\
\hline Proteína E & $28 \%$ & 20 \\
\hline NS1 & $9 \%$ & 25 \\
\hline NS2a & $9 \%$ & 3 \\
\hline NS2b & $17 \%$ & 4 \\
\hline NS3 completa & $33 \%$ & 24 \\
\hline NS3 protease & $31 \%$ & 9 \\
\hline NS3 helicase & $35 \%$ & 12 \\
\hline NS4a & $25 \%$ & 10 \\
\hline NS4b & $22 \%$ & 3 \\
\hline NS5 & $32 \%$ & 42 \\
\hline
\end{tabular}

Para a proteína $\mathrm{NS}_{\mathrm{Hel}}$ do $\mathrm{YFV}$, foram identificadas 12 regiões que possuem características de serem reconhecidas por anticorpos (em amarelo), essas regiões 
contemplam de 1 a 35 aminoácidos. A região com maior score corresponde aos resíduos centrais da $142^{\circ}$ ao $173^{\circ}$ sequência de aminoácidos e, de acordo com o ponto de corte, cerca de 156 aminoácidos estão enquadrados com a assinatura de possíveis epítopos. Considerando essa estimativa e baseado na posição e no tamanho da sequência de aminoácidos pode-se dizer que a NS3 Hel, em sua estrutura linear, possui $35 \%$ de chances (tabela 3) de induzir uma atividade humoral, sendo considerada um antígeno em potencial.

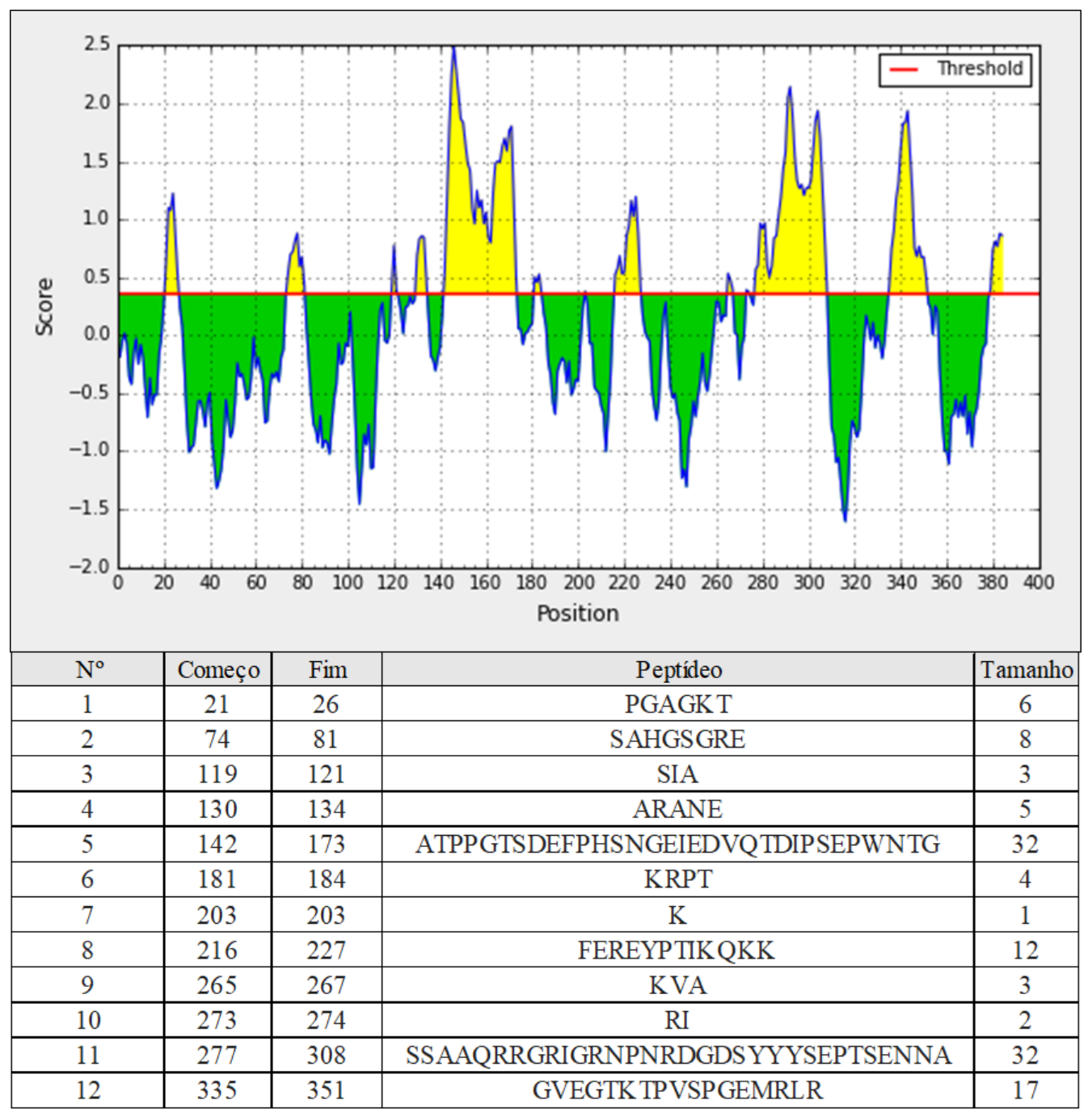

Figura 2: Análise por BepiPred para a predição de epítopos da NS3Hel para YFV; o eixo Y representa a pontuação na escala de flexibilidade para reconhecimento de anticorpos, enquanto o eixo $\mathrm{X}$ representa as posições dos aminoácido. Logo abaixo temos os resultados quantitativos referente a posição dos aminoácidos e o tamanho do fragmento que se enquadra nos scores, mostrando o começo e fim em relação a posição dos aminoácidos. 


\subsection{Padronização do ELISA}

De acordo com ensaios preliminares visando determinar a melhor diluição para o anticorpo primário e a concentração de $\mathrm{NS}_{\mathrm{Hel}}$, observamos que a diluição de 1:100 das amostras e a concentração de $40 \mathrm{ng} / \mathrm{mL}$ de $\mathrm{NS}_{\text {Hel }}$ foram as que responderam de forma adequada.

Metade da placa de ELISA, utilizada neste ensaio, foi sensibilizada com $40 \mathrm{ng}$ de $\mathrm{NS}_{\text {Hel }}$ e paralelamente, sensibilizou-se a outra metade com $10^{4}$ PFU do YFV infeccioso. Tanto as amostras quanto os controles foram analisados em duplicata para pesquisa de anticorpos $\operatorname{IgM}$ e $\operatorname{IgG}$ (Figura 3).

NS3Hel

YFV-WT

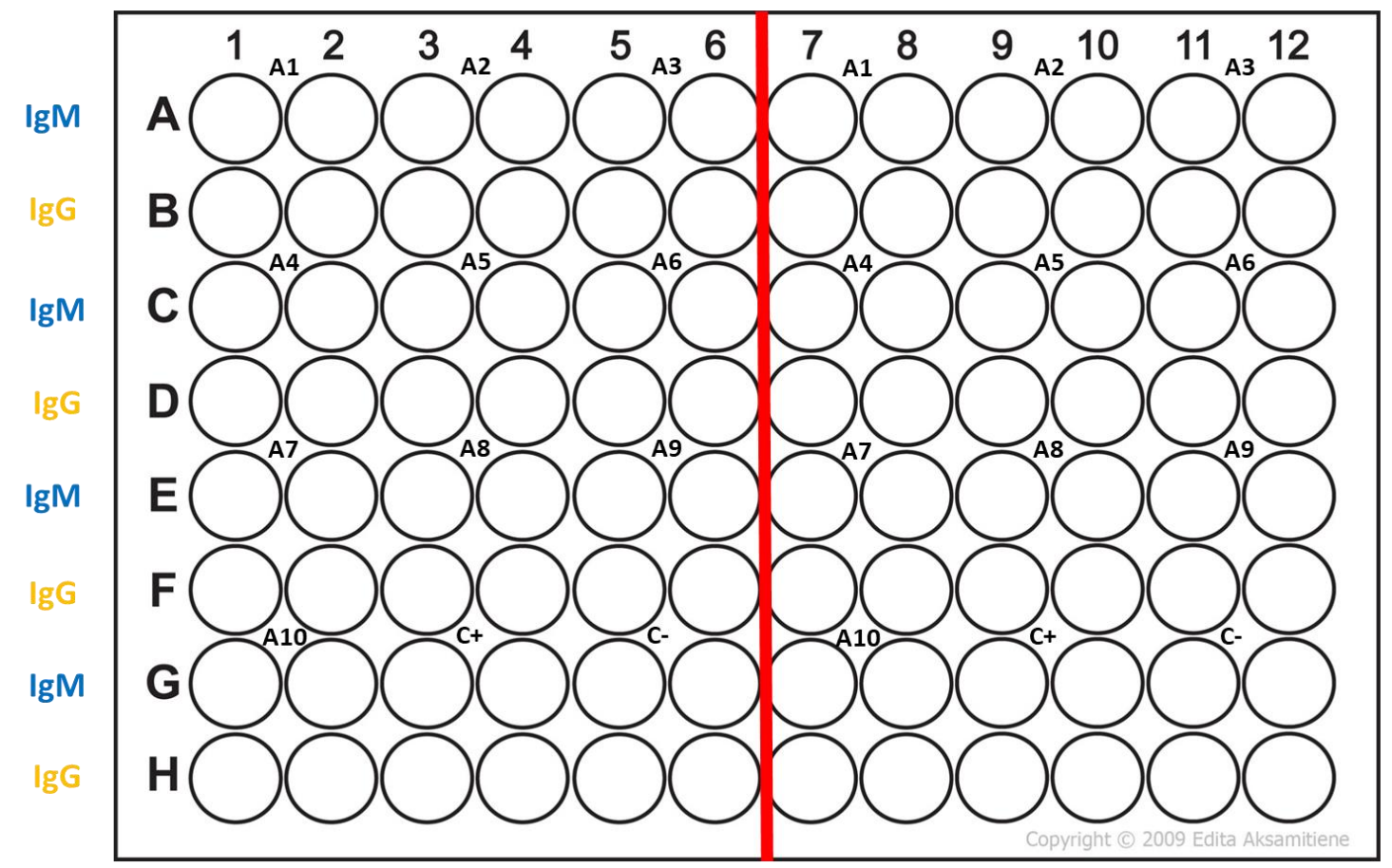

Figura 3: Molde da placa de ELISA para testar as amostras clínicas dos pacientes PRNT positivos para YFV. O ensaio foi feito em duplicata para as amostras (A), onde cada amostra foi testada para IgM e IgG, tanto para NS3Hel quanto YFV-WT. A1: Amostra 1

A tabela 3 mostra as condições de padronização do teste de ELISA usando a $\mathrm{NS} 3_{\text {Hel. }}$ 
Tabela 4. Condições da técnica de ELISA padronizadas utilizando a proteína NS3 $3_{\mathrm{Hel}}$

\begin{tabular}{|c|c|c|c|}
\hline Etapa & Condição & Reagente/buffer & Concentração e volume \\
\hline Sensibilização da placa & $\begin{array}{l}\text { Overnight a } \\
\qquad 4^{\circ} \mathrm{C}\end{array}$ & $\begin{array}{c}\text { Tampão 0,05M } \\
\text { Carbonato- } \\
\text { Bicarbonato }\end{array}$ & $\begin{array}{c}40 \text { ng de } \mathrm{NS} 3_{\text {Hel }} \text { em } 50 \\
\mu \mathrm{l} / \text { poço }\end{array}$ \\
\hline Lavagem & 3 vezes & PBS-Tween $0,2 \%$ & $200 \mu \mathrm{l} / \mathrm{poço}$ \\
\hline Bloqueio & $\begin{array}{c}2 \text { horas a } \\
37^{\circ} \mathrm{C}\end{array}$ & $\begin{array}{l}\text { PBS } 1 \% \text { Leite em } \\
\text { pó desnatado }\end{array}$ & $200 \mu 1 /$ poço \\
\hline Lavagem & 3 vezes & PBS-Tween $0,2 \%$ & $200 \mu 1 /$ poço \\
\hline $\begin{array}{l}\text { Anticorpo primário } \\
\text { (amostra) }\end{array}$ & $\begin{array}{c}2 \text { horas a } \\
37^{\circ} \mathrm{C}\end{array}$ & $\begin{array}{l}\text { PBS 1\% Leite em } \\
\text { pó desnatado }\end{array}$ & $\begin{array}{c}\text { Diluição 1:100 } \\
100 \mu \mathrm{l} / \text { poço }\end{array}$ \\
\hline Lavagem & 3 vezes & PBS-Tween $0,2 \%$ & $200 \mu \mathrm{l} /$ poço \\
\hline Anticorpo secundário & $\begin{array}{l}1 \text { hora a } \\
37^{\circ} \mathrm{C}\end{array}$ & $\begin{array}{l}\text { anti-IgG ou IgM } \\
\text { humano } \\
\text { conjugado com } \\
\text { HRP }\end{array}$ & $\begin{array}{c}\text { Diluição 1:5000 } \\
100 \mu \mathrm{l} / \text { poço }\end{array}$ \\
\hline Lavagem & 4 vezes & PBS-Tween $0,2 \%$ & $200 \mu \mathrm{l} / \mathrm{poço}$ \\
\hline Substrato & $\begin{array}{l}15 \text { minutos } \\
\text { em câmara } \\
\text { escura }\end{array}$ & TMB & $100 \mu \mathrm{l} /$ poço \\
\hline $\begin{array}{c}\text { Solução de parada } \\
\text { (stop) }\end{array}$ & 5 minutos & $\mathrm{HCl} 1 \mathrm{M}$ & $100 \mu \mathrm{l} /$ poço \\
\hline Leitura & $450 / 620 \mathrm{~nm}$ & & \\
\hline
\end{tabular}

\subsection{Teste com as amostras dos pacientes recém-vacinados e vacinados por longos períodos}

Foram avaliadas 37 amostras de soros de pacientes pós vacinados com a vacina 17DD. A comparação foi baseada a partir dos dados obtidos do $\mathrm{PRNT}_{50}$ (dados não mostrados) em um estudo realizado outro aluno do laboratório. Todas as amostras foram PRNT positivas para YF e se enquadravam dentro das características estabelecidas pelo OMS. Esses pacientes foram vacinados e acompanhados por 180 dias. Para o teste de ELISA foram triadas amostras correspondentes aos dias 7, 30, 90 e 180 pós-vacinação. Para cada grupo, testou-se em torno 10 amostras, totalizando 37.

Das 37 amostras testadas 18/37(48,6\%) foram positivas para IgM, enquanto que apenas 9/37(24,4\%) foram positivas para IgG (Tabela 5). Considerando os dias referentes a vacinação, nas amostras de 7 dias, 6/8(75\%) foram positivas para IgM, enquanto que apenas 2/8(25\%) foram positivas para IgG. Já as de 30 dias, 8/10(80\%) para IgM e 4/10(40\%) para IgG. Em 90 dias temos 2/10(20\%) positivas para IgM e 2/10(20\%) positivas para IgG. Por fim, as de 180 dias 2/10(20\%) para IgM e 1/10(10\%) para IgG. 
Tabela 5. Positividade para o YFV em amostras de pacientes pós-vacinados e PRNT+ utilizando a NS3 $3_{\text {Hel }}$ e o Vírus da Febre Amarela Selvagem (YFV-WT) como antígeno de captura

\begin{tabular}{|c|c|c|c|c|}
\hline \multirow[b]{2}{*}{ Dias } & \multicolumn{2}{|c|}{ ELISA-NS3Hel } & \multicolumn{2}{|c|}{ ELISA-YFV in house } \\
\hline & IgM & $\mathrm{IgG}$ & $\operatorname{IgM}$ & $\mathrm{IgG}$ \\
\hline 7 & $6 / 8$ & $2 / 8$ & $5 / 8$ & $8 / 8$ \\
\hline 30 & $8 / 10$ & $4 / 10$ & $0 / 10$ & $9 / 10$ \\
\hline 90 & $2 / 10$ & $2 / 10$ & $0 / 10$ & $10 / 10$ \\
\hline 180 & $2 / 10$ & $1 / 10$ & $1 / 10$ & $4 / 10$ \\
\hline Total: & $18 / 38$ & $9 / 38$ & $6 / 38$ & $31 / 38$ \\
\hline
\end{tabular}

De forma paralela, testou-se adicionalmente 48 amostras que foram PRNT positivas ou negativas para YFV, a única diferença é que esses pacientes já haviam sido vacinados com 17DD em um intervalo de tempo maior (Tabela 6). Das amostras testadas $27 \%(13 / 48)$ foram positivas para $\operatorname{IgM}$, enquanto que $21 \%(10 / 48)$ foram positivas para IgG no ELISA-NS3Hel.

Tabela 6. Positividade para ELISA-NS3 $3_{\text {Hel }}$ e YFV para pacientes PRNT positivo ou negativos que foram vacinados a mais de 1 ano

\begin{tabular}{|c|l|c|c|c|c|c|c|c|}
\hline Amostra & DENV & ZIKV & $\begin{array}{c}\text { Ano de } \\
\text { vacinação } \\
\text { 17DD }\end{array}$ & $\begin{array}{c}\text { PRNT } \\
\mathbf{p} / \\
\text { YFV }\end{array}$ & IgM/NS3 & IgG/NS3 & IgM/YFV & IgG/YFV \\
\hline 1 & & & 2013 & $(+)$ & & & & \\
\hline 2 & & & 2017 & $(+)$ & $(+)$ & & $(+)$ & \\
\hline 3 & & & 2013 & $(+)$ & $(+)$ & $(+)$ & $(+)$ & \\
\hline 4 & & & 2010 & $(+)$ & $(+)$ & $(+)$ & $(+)$ & $(+)$ \\
\hline 5 & & & 2016 & $(+)$ & $(+)$ & $(+)$ & $(+)$ & \\
\hline 6 & & & 2011 & $(+)$ & $(+)$ & $(+)$ & $(+)$ & \\
\hline 7 & & & 2018 & $(+)$ & $(+)$ & & $(+)$ & $(+)$ \\
\hline 8 & & & 2017 & $(+)$ & $(+)$ & & & \\
\hline 9 & & & 2015 & $(+)$ & $(+)$ & $(+)$ & $(+)$ & $(+)$ \\
\hline 10 & & & 2014 & $(+)$ & $(+)$ & $(+)$ & $(+)$ & $(+)$ \\
\hline 11 & & & 2017 & $(+)$ & & & & $(+)$ \\
\hline 12 & & & 2013 & $(+)$ & & & & $(+)$ \\
\hline 13 & & & 2006 & $(+)$ & & & & $(+)$ \\
\hline 14 & & & 2013 & $(+)$ & $(+)$ & & & $(+)$ \\
\hline 15 & & & 2009 & $(+)$ & & & & $(+)$ \\
\hline 16 & & & 2010 & $(+)$ & $(+)$ & $(+)$ & $(+)$ & $(+)$ \\
\hline 17 & & & & $(-)$ & & & & $(+)$ \\
\hline 18 & & & 2009 & $(+)$ & & & $(+)$ & $(+)$ \\
\hline 19 & & & 2013 & $(+)$ & & & & $(+)$ \\
\hline 20 & & & 2012 & $(+)$ & & $(+)$ & $(+)$ & $(+)$ \\
\hline
\end{tabular}




\begin{tabular}{|c|c|c|c|c|c|c|}
\hline 21 & 2009 & $(+)$ & $(+)$ & $(+)$ & & \\
\hline 22 & - & $(+)$ & & & & $(+)$ \\
\hline 23 & 2009 & $(+)$ & & $(+)$ & & $(+)$ \\
\hline 24 & 2016 & $(+)$ & & & & $(+)$ \\
\hline 25 & 2008 & $(+)$ & & & & \\
\hline 26 & 2013 & $(+)$ & $(+)$ & & & $(+)$ \\
\hline 27 & - & $(+)$ & & & & $(+)$ \\
\hline 28 & - & $(+)$ & & & & $(+)$ \\
\hline 29 & 2010 & $(+)$ & & & & $(+)$ \\
\hline 30 & - & $(+)$ & & & & $(+)$ \\
\hline 31 & 2009 & $(+)$ & & & & \\
\hline 32 & 2017 & $(+)$ & & & & $(+)$ \\
\hline 33 & 2008 & $(+)$ & & & & 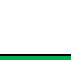 \\
\hline 34 & 2011 & $(+)$ & & & & $(+)$ \\
\hline 35 & 2016 & $(+)$ & & & & $(+)$ \\
\hline 36 & 2017 & $(+)$ & & & & $(+)$ \\
\hline 37 & 2007 & $(+)$ & & & & \\
\hline 38 & 2016 & $(-)$ & & & & \\
\hline 39 & 2010 & $(-)$ & & & & $(+)$ \\
\hline 40 & 2000 & $(+)$ & & & & \\
\hline 41 & 2009 & $(-)$ & & & & \\
\hline 42 & & $(-)$ & & & & $(+)$ \\
\hline 43 & & $(-)$ & & & & $(+)$ \\
\hline 44 & & $(-)$ & & $(+)$ & $(+)$ & \\
\hline 45 & 2007 & $(+)$ & & & & \\
\hline 46 & 2007 & $(+)$ & & & & \\
\hline 47 & 2013 & $(+)$ & & & $(+)$ & $(+)$ \\
\hline 48 & & $(-)$ & & & & \\
\hline
\end{tabular}

*Caixa vermelha: Não vacinados; *Caixa verde: Amostra positiva

\subsection{Reatividade cruzada entre DENV e ZIKV}

Para verificar a reatividade cruzada entre os vírus DENV e ZIKV, utilizou-se amostras humanas de fase aguda da doença. A triagem das amostras positivas de dengue baseou-se na presença de anticorpos $\operatorname{IgM}$ e/ou IgG, e na presença de antígenos, NS1(dando preferência para aquelas que eram IgM positivas) por kit de ELISA comercial e/ou testes imunocromatrográficos, enquanto as amostras positivas para ZIKV foram triadas por RT-qPCR positivo e PRNT positivo. O resultado para o ELISA-NS3 Hel está representado na tabela 6. Em paralelo realizou-se o ELISA-YFV para comparar com a 
partícula viral completa. No total, 21 amostras de fase aguda para DENV e 10 amostras para ZIKV foram testadas (Tabelas 6 e 7).

Tabela 7. Resultado do ELISA dos pacientes com NS1/IgM/IgG e PCR positivos para DENV

\begin{tabular}{|c|c|c|c|c|c|c|c|c|c|}
\hline Amostra & $\begin{array}{c}\text { IgM } \\
\text { DENV }\end{array}$ & $\begin{array}{c}\text { IgG } \\
\text { DENV }\end{array}$ & NS1 & PCR & $\begin{array}{c}\text { PRNT } \\
\text { p/ } \\
\text { YFV }\end{array}$ & $\begin{array}{l}\text { IgM } \\
\text { NS3 }\end{array}$ & $\begin{array}{l}\text { IgG } \\
\text { NS3 }\end{array}$ & $\begin{array}{l}\text { IgM } \\
\text { YFV }\end{array}$ & $\begin{array}{l}\text { IgG } \\
\text { YFV }\end{array}$ \\
\hline 1 & $(+)$ & $(+)$ & $(+)$ & DENV2 & $(+)$ & $(-)$ & $(-)$ & $\mathrm{C}$ & $(+)$ \\
\hline 2 & & & & DENV2 & $(+)$ & $(-)$ & $(-)$ & $(-)$ & $(+)$ \\
\hline 3 & $(+)$ & $(+)$ & & & $(+)$ & $(-)$ & $(-)$ & $(-)$ & $(+)$ \\
\hline 4 & $(+)$ & $(+)$ & & DENV2 & $(+)$ & $(-)$ & $(-)$ & $(-)$ & $(+)$ \\
\hline 5 & & & $(+)$ & DENV2 & $(-)$ & $(-)$ & $(-)$ & $(+)$ & $(+)$ \\
\hline 6 & $(+)$ & $(+)$ & & & $(+)$ & $(-)$ & $(-)$ & $(-)$ & $(-)$ \\
\hline 7 & $(+)$ & $(+)$ & & & $(+)$ & $(-)$ & $(-)$ & $(-)$ & $(+)$ \\
\hline 8 & $(+)$ & & & & $(+)$ & $(-)$ & $(+)$ & $(-)$ & $(+)$ \\
\hline 9 & $(+)$ & $(+)$ & & & $(+)$ & $(-)$ & $(-)$ & $(-)$ & $(+)$ \\
\hline 10 & $(+)$ & & & & $(+)$ & $(-)$ & $(-)$ & $(-)$ & $(+)$ \\
\hline 11 & $(+)$ & & & & $(+)$ & $(-)$ & $(-)$ & $(-)$ & $(-)$ \\
\hline 12 & $(+)$ & $(+)$ & & & $(+)$ & $(-)$ & $(-)$ & $(-)$ & $(+)$ \\
\hline 13 & $(+)$ & $(+)$ & & & $(+)$ & $(-)$ & $(-)$ & $(-)$ & $(-)$ \\
\hline 14 & $(+)$ & $(+)$ & & & $(+)$ & $(-)$ & $(-)$ & $(-)$ & $(+)$ \\
\hline 15 & $(+)$ & $(+)$ & & & $(+)$ & $(-)$ & $(-)$ & $(-)$ & $(+)$ \\
\hline 16 & $(+)$ & $(+)$ & & & $(+)$ & $(-)$ & $(-)$ & $(-)$ & $(+)$ \\
\hline 17 & $(+)$ & & & & $(+)$ & $(-)$ & $(-)$ & $(+)$ & $(+)$ \\
\hline 18 & $(+)$ & $(+)$ & $(+)$ & & $(+)$ & $(-)$ & $(-)$ & $(+)$ & $(+)$ \\
\hline 19 & $(+)$ & $(+)$ & & & $(+)$ & $(-)$ & $(-)$ & $(+)$ & $(+)$ \\
\hline 20 & $(+)$ & $(+)$ & $(+)$ & DENV2 & $(+)$ & $(-)$ & $(-)$ & $(-)$ & $(-)$ \\
\hline 21 & $(+)$ & & & & $(+)$ & $(+)$ & $(-)$ & $(-)$ & $(+)$ \\
\hline
\end{tabular}

*Laranja: Dados de DENV;

*Verde: Teste positivo

Tabela 8. Resultado do teste de ELISA para pacientes que são PCR e/ou PRNT positivos para ZIKV

\begin{tabular}{|c|c|c|c|c|c|c|c|}
\hline Amostra & PCR+ & $\begin{array}{c}\text { PRNT } \\
\text { p/ } \\
\text { ZIKV }\end{array}$ & $\begin{array}{c}\text { PRNT } \\
\text { p/ } \\
\text { YFV }\end{array}$ & IgM/NS3 & IgG/NS3 & IgM/YFV & IgG/YFV \\
\hline 1 & $(+)$ & $(+)$ & $(+)$ & $(-)$ & $(-)$ & $(-)$ & $(+)$ \\
\hline 2 & $(+)$ & $(+)$ & $(+)$ & $(-)$ & $(-)$ & $(-)$ & $(+)$ \\
\hline 3 & & $(+)$ & $(+)$ & $(-)$ & $(-)$ & $(-)$ & $(-)$ \\
\hline 4 & $(+)$ & & $(+)$ & $(-)$ & $(-)$ & $(-)$ & $(+)$ \\
\hline 5 & $(+)$ & $(+)$ & $(+)$ & $(-)$ & $(-)$ & $(-)$ & $(+)$ \\
\hline 6 & & $(+)$ & $(+)$ & $(-)$ & $(-)$ & $(-)$ & $(-)$ \\
\hline 7 & & $(+)$ & $(-)$ & $(-)$ & $(-)$ & $(-)$ & $(-)$ \\
\hline
\end{tabular}




\begin{tabular}{c|c|c|c|c|c|c|c}
\cline { 5 - 6 } 8 & $(+)$ & $(-)$ & $(-)$ & $(-)$ & $(-)$ & $(-)$ \\
\hline 9 & & $(+)$ & $(-)$ & $(-)$ & $(-)$ & $(-)$ & $(-)$ \\
\hline 10 & & $(+)$ & $(-)$ & $(-)$ & $(-)$ & $(-)$ & $(-)$ \\
\hline
\end{tabular}

*Laranja: Dados de ZIKV;

*Verde: Teste positivo

No total das 21 amostras de fase aguda de DENV, 4,8(1/21) foram positivas para IgM e IgG, enquanto que nenhuma amostra foi positiva para ZIKV. Por outro lado, quando as amostras foram testadas para ELISA-YFV, 19\%(4/21) foram positivas para $\operatorname{IgM}$ e $80 \%$ foram positivas para IgG, enquanto que nenhuma amostra de ZIKV foram positivas para $\operatorname{IgM}$ e 40\%(4/10) foram positivas para $\operatorname{IgG}$ (Tabela 8).

Tabela 9. Positividade para o YFV em amostras de pacientes diagnosticados laboratorialmente com DENV-2 e ZIKV usando a NS3 ${ }_{\text {Hel }}$ e YFV para verificar reatividade cruzada

\begin{tabular}{cc|c|c|c}
\hline \multirow{2}{*}{ Dias } & \multicolumn{2}{c|}{ ELISA-NS3 } & \multicolumn{2}{c}{ ELISA-YFV in house } \\
\cline { 2 - 5 } & $\operatorname{IgM}$ & $\operatorname{IgG}$ & $\operatorname{IgM}$ & $\operatorname{IgG}$ \\
\hline DENV-2 & $1 / 21$ & $1 / 21$ & $4 / 21$ & $17 / 21$ \\
\hline ZIKV & $0 / 10$ & $0 / 10$ & $0 / 10$ & $4 / 10$ \\
\hline
\end{tabular}

\subsection{Análise da sensibilidade e especificidade do ELISA-NS3 Hel}

Totalizando, tivemos 32 amostras positivas para IgM e 20 positivas para $\operatorname{IgG}$ pelo ELISA-NS3 $3_{\mathrm{Hel}}$, enquanto que para o ELISA-YFV, 24 foram positivas para IgM e 82 positivas para IgG (Tabela 10).

Tabela 10. Total de amostras positivas e negativas para o teste de ELISA-NS3 $3_{\mathrm{Hel}} \mathrm{e}$ ELISA-YFV

\begin{tabular}{c|c|c|c}
\hline & IgM & IgG & Total \\
\hline ELISA-NS3 ${ }_{\mathrm{Hel}}$ & $32 / 117$ & $20 / 117$ & $52 / 117$ \\
\hline ELISA-YFV & $24 / 117$ & $82 / 117$ & $106 / 117$ \\
\hline
\end{tabular}

Considerando os dados referentes a positividade de todas as amostras, fez o cálculo da sensibilidade e especificidade da técnica utilizando como referência o ensaio de PRNT das amostras. A tabela 11 mostra os resultados de sensibilidade e especificidade dos dois testes comparados, tanto para IgM quanto para IgG, respectivamente. 
Tabela 11. Sensibilidade e especificidade para IgM e IgG do ELISA-NS3 ${ }_{\mathrm{Hel}}$ comparado com os dados de PRNT

\begin{tabular}{|c|c|c|}
\hline & \multicolumn{2}{|c|}{ IgM } \\
\hline \multirow[b]{2}{*}{ ELISA-NS3 3 Hel } & Sensibilidade (\%) & Especificidade (\%) \\
\hline & 29,2 & 100 \\
\hline \multirow[t]{3}{*}{ ELISA-YFV } & 19 & 92,3 \\
\hline & \multicolumn{2}{|c|}{ IgG } \\
\hline & Sensibilidade (\%) & Especificidade (\%) \\
\hline ELISA-NS3 $3_{\mathrm{Hel}}$ & 18,5 & 100 \\
\hline ELISA-YFV & 76 & 86 \\
\hline
\end{tabular}

Posteriormente aos cálculos de sensibilidade e especificidade, verificou-se a acurácia, valor preditivo positivo (VPP), valor preditivo negativo (VPN) e a razão de verossimilhança. A acurácia informa a proporção dos testes serem corretos dentre todos os resultados obtidos. O VPP mostra a probabilidade do teste positivo realmente ser positivo, enquanto que o VPN mostra o mesmo parâmetro só que dentro do teste negativo não ter a mesma condição, já a razão de verossimilhança mostra a probabilidade de um teste positivo ser realmente de um indivíduo doente em relação a um não doente. No caso da razão de verossimilhança, o resultado varia de 1 ao infinito, quanto mais próximo de zero, indica que a probabilidade do teste ser positivo para indivíduos doentes e não doentes é a mesma, indicando assim que o teste é inútil. Quando este valor é superior a 1 indica que a probabilidade de que o teste seja positivo apenas para os indivíduos que estão doentes, é alta. Quando a probabilidade é infinita, significa que o teste só é positivo para indivíduos que são doentes.

Tabela 12. Acurácia, VPP, VPN e Razão de Verossimilhança para o teste positivo $(\mathrm{RV}+)$ do teste de ELISA-NS3 ${ }_{\mathrm{Hel}}$ comparado com ELISA-YFV

\begin{tabular}{|c|c|c|c|c|c|c|c|c|}
\hline & \multicolumn{4}{|c|}{ IgM } & \multicolumn{4}{|c|}{ IgG } \\
\hline Teste & $\begin{array}{c}\text { Acuráci } \\
\text { a }\end{array}$ & VPP & VPN & $\mathrm{RV}+$ & $\begin{array}{c}\text { Acuráci } \\
\text { a }\end{array}$ & VPP & VPN & $\mathrm{RV+}$ \\
\hline $\begin{array}{l}\text { ELISA- } \\
\mathrm{NS} 3_{\mathrm{Hel}} \\
\end{array}$ & $30 \%$ & $100 \%$ & $16,3 \%$ & Infinito & $19 \%$ & $100 \%$ & $14 \%$ & Infinito \\
\hline $\begin{array}{l}\text { ELISA- } \\
\text { YFV }\end{array}$ & $20 \%$ & $95 \%$ & $18 \%$ & 2.5 & $79 \%$ & $97,5 \%$ & $33 \%$ & 5.35 \\
\hline
\end{tabular}

A curva ROC (Receiver Operator Characteristic) é uma ferramenta gráfica que serve para avaliar o desempenho de um teste. Ela tem como objetivo demonstrar a habilidade do teste em discriminar os diferentes diagnósticos da condição, se tornando 
uma ferramenta mais robusta para avaliar sensibilidade e especificidade (88). É uma forma de representar a relação, que normalmente é antagónica, entre a sensibilidade e a especificidade de um teste diagnóstico, ao longo de um contínuo de valores de a partir de um ponto de corte. A Figura 4 mostra a curva de ROC para os testes de ELISA-NS3 $3_{\text {Hel }}$ e YFV, tanto para IgM quanto para IgG a partir dos dados do PRNT.
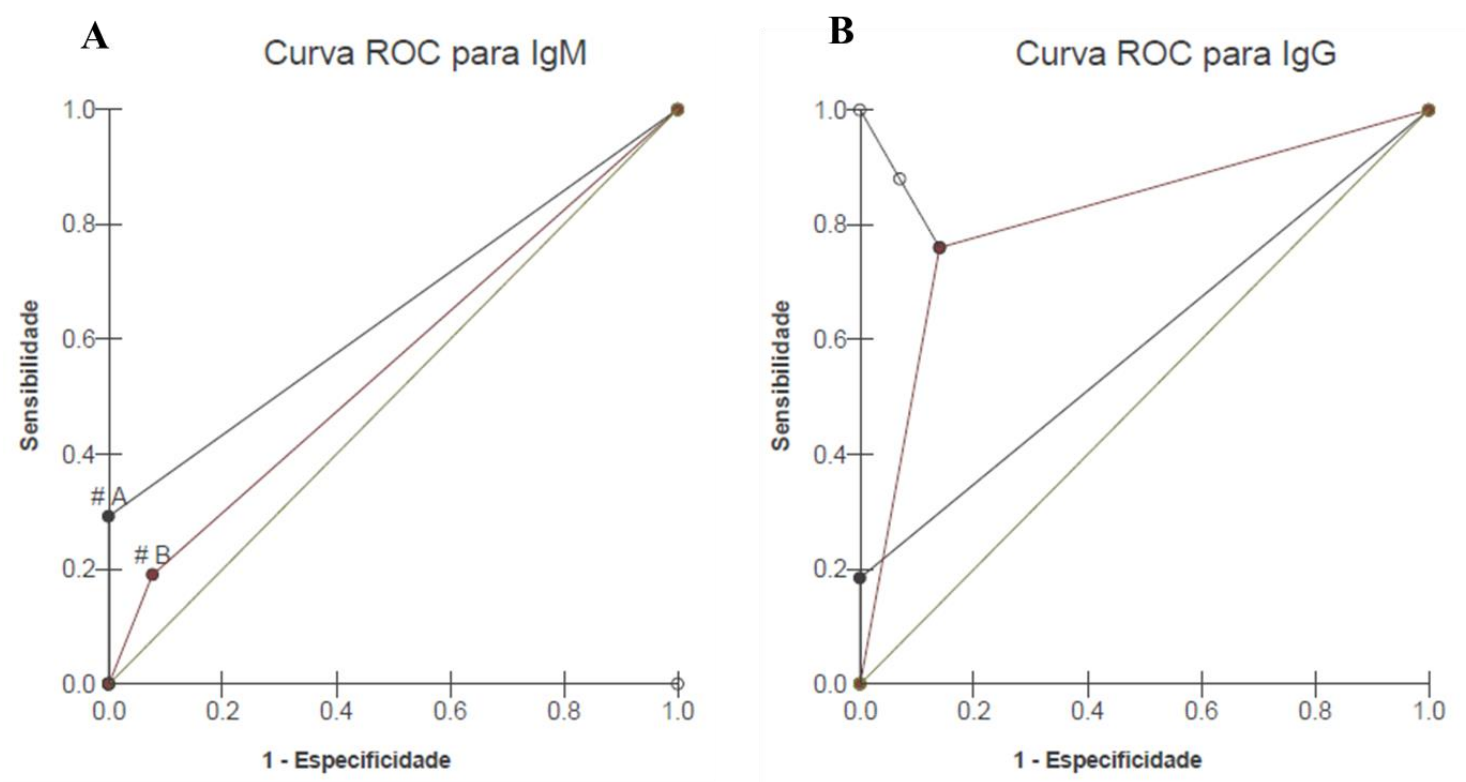

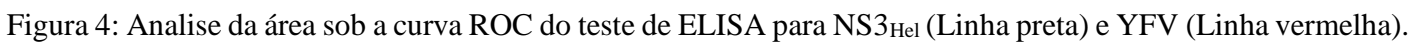
A: Curva ROC dos testes para IgM; B: Curva ROC dos testes para IgG. O ponto de corte foi definido a partir do resultado do PRNT das 117 amostras testadas

\subsection{Ensaio de avidez dos anticorpos anti-YFV vs NS3Hel}

Analisando o ensaio de avidez dos anticorpos para NS3 $3_{\text {Hel }}$ em amostras humanas, $80 \%$ e $11 \%$ das amostras foram classificadas como "alta avidez" e "avidez média", respectivamente, para $\operatorname{IgM}$, enquanto que $100 \%$ das amostras IgG positivas para NS3 $\mathrm{Hel}$ foram classificadas com "alta avidez". Estes resultados estão representados na figura 5. 

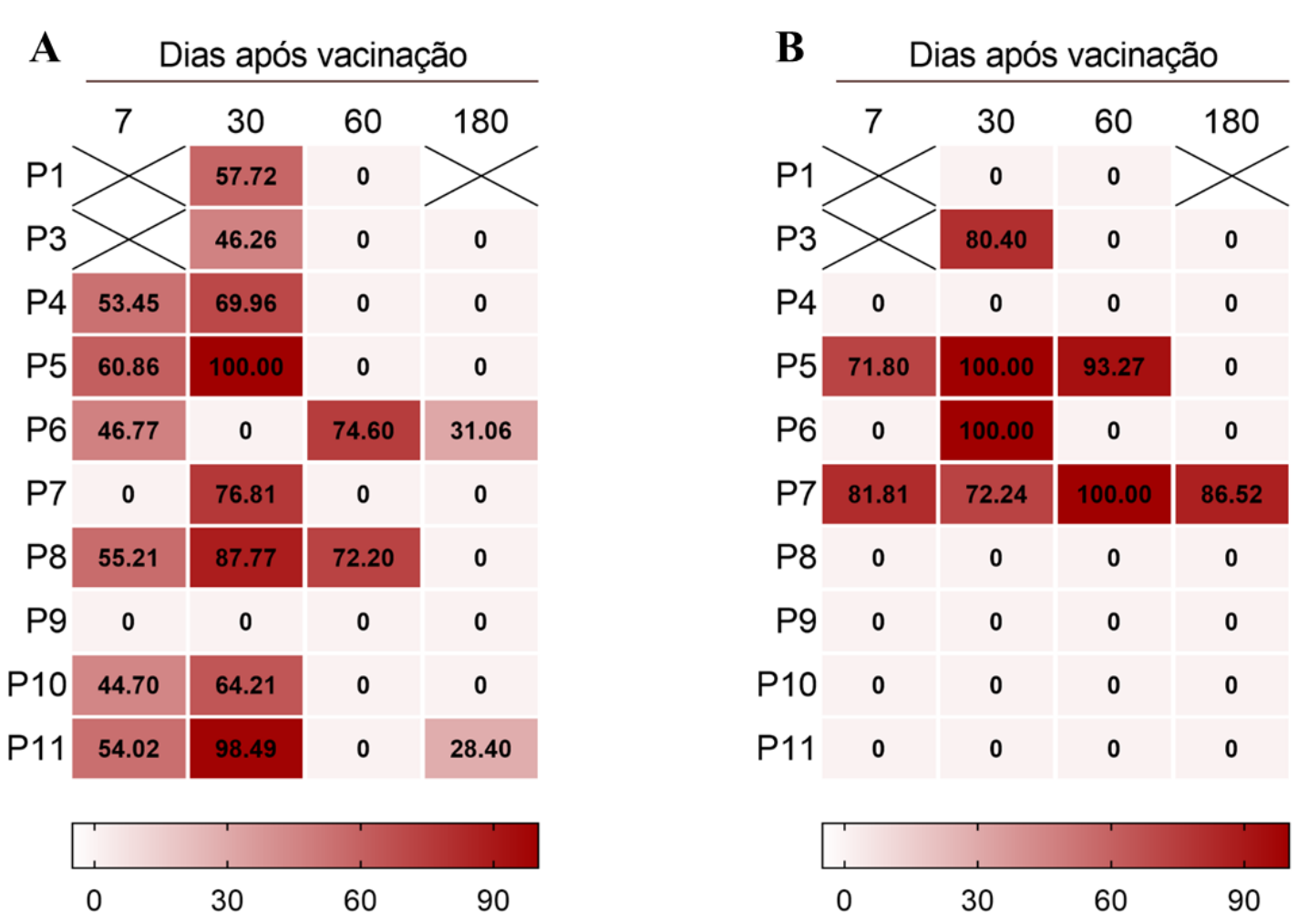

Figura 5: Avidez de anticorpos anti-YFV em amostras IgM (A) e IgG (B) positivas para o ELISA para NS3 Hel. Anticorpo com avidez de 0-30\% são consideradas de baixa avides, de 30-50\% são de média avidez e >50\% são de alta avidez 


\section{DISCUSSÃO}

Até o momento, não existem kits IgM-ELISA validados e comercialmente disponíveis para o diagnóstico de Febre Amarela. Portanto, os protocolos in house utilizando antígenos purificados são os mais utilizados para a realização dos testes $(7,9)$. A reatividade cruzada dos testes de IgM para a febre amarela com outros flavivírus já foi descrita e é significativa, principalmente em infecções secundárias por outros flavivírus. Desta forma, em áreas onde outros flavivírus circulam (especialmente os DENV e ZIKV), a probabilidade de reatividade cruzada é muito alta.

O papel das proteínas não estruturais vem ganhando destaque no uso de diagnóstico de fase aguda das infecções de alguns flavivírus (65, 68, 79, 78). Algumascaracterísticas dessas proteínas são importantes e podem refletir no seu uso para o diagnóstico diferencial. Um ponto importante é que essas proteínas são sintetizadas em grandes quantidades em infecções primarias, uma vez que elas fazem parte da maquinaria para a produção de novos vírus, isso permite que neste momento da infecção elas tenham um limiar de detecção muito menor comparado com infecções secundarias, fazendo assim o diferencial de infecções primarias e secundarias, assim como permitir distinguir eficiência de vacinação com infecção real $(49,67)$.

No caso do YFV, as proteínas mais imunogênicas consistem na proteína do envelope (E) e na NS3, no entanto, essa imunogenicidade da NS3 está muito mais associada a resposta imune celular. Isso corrobora com os dados de Van Der Most (2002), onde foi demonstrado que os resíduos de maior imunogenicidade para células TCD4 e TCD8, estão na NS3. A resposta imunológica dessas proteínas está mais restrita a resposta imune celular, porém foi possível observar que as mesmas proteínas são capazes de induzir uma forte resposta imune humoral e poderiam ser usadas como ferramentas para diagnóstico sorológico, isso foi mostrado com DENV, ZIKV, Bluetongue virus (BTV), Foot-and-Mouth virus (FMV) (47, 62, 73, 75, 79). Assim, considerou-se também a hipótese de que a NS3 seria uma candidata para a realização do diagnóstico sorologico de Febre Amarela, inferindo-se partir dos dados de literatura, uma vez que ela tem uma imunogenicidade celular bem elevada, sendo essa hipótese feita também em associação com os ensaios in silico de predição dos epítopos para NS3 e as demais proteínas de YFV.

Os ensaios de predição de epítopos da NS3 mostrou que a mesma possui 35\% de chances de ser um potencial antígeno para reconhecimento de anticorpos, de acordo com a ferramenta de predição BepiPrep, da IEDB. Os valores de predições são inferências 
baseadas na estrutura e características físico-químicas do peptídeo, podendo ser um resultado subestimado ou superestimado, uma vez que grande parte dessas modificações podem refletir em sua atividade biológica. A interação entre anticorpos e antígenos é um dos mecanismos mais importantes do sistema imunológico para neutralizar e remover organismos infecciosos do hospedeiro.

A identificação dos epítopos restritos às células B é essencial em várias aplicações biomédicas, como: desenho de candidatos vacinais, desenvolvimento de diagnóstico para várias doenças e desenvolvimento de imunoterapêuticos. No entanto, o mapeamento experimental de epítopos nos proporciona inferências significativas antes de extrapolarmos para o modelo biológico in vivo, tornando os métodos in silico uma abordagem atrativa. Até então, o desempenho relatado de métodos para o mapeamento in silico de epítopos restrito ás células B tem sido moderado. Porém, várias questões relacionadas aos dados referentes a essas analises podem ser subestimados. Raramente, todos os potenciais epítopos em estudos in silico são definidos como antígeno, devemos considerar que, geralmente, os anticorpos são produzidos contra o antígeno em sua forma nativa e dentro de um determinado contexto biológico e não contra o monômero do antígeno, no caso de peptídeos recombinantes, por exemplo. O tratamento inadequado desses aspectos analíticos pode levar a muitas previsões errôneas e, portanto, gerar um desempenho incorreto quando extrapolamos para ensaios in vitro e in vivo (88). Portanto, o aumento do conhecimento sobre de uma proteína alvo pode aumentar a compreensão dos processos moleculares nos quais ela participa, e assegurar se as modificações que vão ocorrer durante a sua expressão vão de fato influenciar no desenvolvimento dos ensaios (84).

A segunda característica que consideramos para o uso da NS3 no diagnóstico de Febre Amarela, é que essas proteínas (destacando para NS3) são extremamente conservadas entre os flavivírus, reflexo de sua importância na maquinaria de replicação, além do mais, por se tratarem de padrões moleculares associados a patógenos (PAMPS), podem potencializar a produção de citocinas que modulam a resposta imune humoral e celular, justificando o motivo de apresentarem uma imunogenicidade tão elevada (10).

Ainda assim, no uso da NS3, optou-se por utilizar o seu domínio de helicase. A escolha baseou-se pelo fato de que recentemente desenvolveu-se uma vacina inativada de DENV utilizando a NS3 recombinante, do mesmo vírus, como adjuvante, no entanto, clonou-se também, separadamente, os domínios de helicase e protease, sendo que o de helicase foi o que apresentou as características imunogênicas de maior destaque (11), por 
outro lado, em predições comparativas realizadas em nosso laboratório com as outras proteínas de YFV, mostrou-se que o peptideo linear do domínio de helicase da NS3 possui probabilidade de reconhecimento superior que as demais, considerando o score de imunogenicidade para anticorpos, sugerindo assim que ela poderia ser de escolha satisfatória para verificar a hipótese (Tabela 3).

Desta forma, procurou-se verificar a utilidade da NS3 ${ }_{\mathrm{Hel}}$ na detecção de anticorpos da classe IgM e IgG em pacientes pós vacinados com 17DD. As amostras correspondiam ao soro dos dias 7, 30, 90 e 180 pós vacinação. Das amostras testadas 18 foram positivas para IgM e 9 positivas para $\operatorname{IgG}$, sendo que das 18 positivas para $\operatorname{IgM}, 14$ correspondiam aos dias 7 e 30. Este dado corrobora com Narayan et al. (2020) onde 20 amostras de fase aguda para DENV testadas para NS5 foram 100\% positivas para IgM, enquanto que nenhuma foi positiva para IgG.

Inicialmente, acreditou-se que a positividade para IgM poderia estar associada com atividade cruzada com os vírus DENV e ZIKV, para verificar tal hipótese, as amostras foram submetidas ao teste de ELISA comercial de captura para IgM. Porém, os testes mostraram que as amostras não foram positivas (dados não mostrados), sugerindo que o ELISA-NS3 $3_{\text {Hel }}$ de fato detectou anticorpos da classe IgM para YFV. Sugere-se então que a NS3 $3_{\text {Hel }}$ teria uma importância na fase aguda da infecção onde se tem a replicação do vírus, e apesar da vacinação se tratar de um vírus atenuado, a mimetização da replicação viral pode reproduzir os resultados obtidos. Neste contexto tivemos duas limitações, a primeira consiste em saber se estes pacientes eram de fato primo-vacinados, uma vez que a revacinação poderia inviabilizar a presença de anticorpos da classe IgM, já que os indivíduos teriam soroconvertidos, e a segunda limitação foi que as amostras testadas foram apenas de pacientes vacinados e não em indivíduos que foram infectados com o vírus selvagem, uma vez que neste caso, poderíamos desassociar uma infecção natural de uma infecção por ação de uma vacina atenuada.

Em relação a reatividade cruzada entre os vírus ZIKV e DENV, foi-se observado um dado inédito. Sob as mesmas condições e utilizando amostras de fase aguda de ambas as infecções, observou-se que nenhuma das amostras positivas para ZIKV foram IgM positivas, enquanto que apenas uma amostra foi positiva para DENV, tanto IgM quanto IgG. Esta positividade para DENV pode ter sido resultado de alguma reação inespecífica. Como paralelamente o ELISA foi realizado utilizando as proteínas estruturais do YFV (partícula inteira) como antígeno de captura, observou-se positividade para $\operatorname{IgM}$ e $\operatorname{IgG}$, fenômeno observado devido à alta reatividade cruzada para os epitopos estruturais 
(fenômeno já observado entre os flavivirus) e devido a resultado de vacinação, respectivamente $(67,85)$.

O gênero Flavivirus é constituído de aproximadamente 70 vírus conhecidos, e os mesmos são organizados em serocomplexos (7). Souza et al (2019) mostrou este fenômeno com amostras de 79 indivíduos vacinados com 17DD. No estudo, a ausência (ou mínima) de reatividade cruzada com anticorpos neutralizantes ao YFV foi um achado relevante, uma vez considerando que a vacina faz parte do cronograma oficial de vacinação em muitas regiões do Brasil e em outros países da América Latina e também porque recomendação de imunização está sendo ampliada devido à situação epidêmica (85).

Nas infecções humanas, este fenômeno resulta na produção de anticorpos que podem reagir de forma cruzadas entre as espécies (4, 67, 68). A influência desta imunidade reativa aos diferentes sorocomplexos durante infecções secundarias ainda não está claramente definida; entretanto, vários estudos sugerem que os anticorpos reativos cruzados podem ser protetores $(66,67)$. Apesar da reatividade favorecer uma imunidade protetiva eficiente, para diagnóstico sorológico, este fenômeno causa confusões na conclusão do prognóstico, desta forma a NS3 Hel utilizada como antígeno de captura, não apresentou este fenômeno, estando associada apenas ao YFV.

Quando avaliado a abordagem diagnóstica tanto para o teste de ELISA-NS3 $3_{\mathrm{Hel}}$ quanto para o ELISA-YFV, tendo como referência o ensaio de PRNT, vimos que a sensibilidade caiu absurdamente, sendo inferior a 30\%, tanto para IgM quanto para IgG, em relação ao teste de ELISA-NS3Hel, porém, observou-se que a especificidade para as duas classes de imunoglobulinas era de $100 \%$, ao passo de que para o ELISA-YFV a especificidade era de $92,3 \%$ e $86 \%$ para IgM e IgG, respectivamente. Ricciardi-Jorge T et al (2017) testou um painel de 73 amostras humanas para demonstrar a adequação da NS1 de YFV como uma ferramenta de diagnóstico, resultando em $80 \%$ de sensibilidade, $100 \%$ de especificidade, $100 \%$ de valor preditivo positivo e $95,5 \%$ de valor preditivo negativo, neste caso, foi-se usando amostras de fase aguda da doença, tendo como metodologia padrão ouro para calcular a abordagem diagnóstica o resultado do teste de RT-qPCR (83). No geral, a sensibilidade e especificidade do teste mostrou-se muito satisfatória, mas devemos considerar que a proteína NS1 é secretada no espaço extracelular e como é secretada em grandes quantidades durante a infecção, é um marcador muito utilizado para diagnóstico de fase aguda de infecção por DENV, sendo que este fenômeno não se reflete para a NS3 e as demais proteínas não-estruturais. 
Ainda assim, buscando então descartar a hipótese de que a positividade para IgM seria de fato relativo a imunização pela vacina e não devido a reatividade cruzada, foi-se realizado o teste de avidez de anticorpos. Esse método é usado para testes sorológicos de rotina para o ZIKV em regiões endêmicas para DENV e também para estudos de vigilância serológica e em gestantes, que ajuda a esclarecer questões epidemiológicas, transmissão e complicações, uma vez que ajuda a distinguir infecções secundarias de primaria (82). O tratamento com ureia após a incubação com o anticorpo primário (soro dos pacientes) remove qualquer reação inespecífica entre os anticorpos e a proteína recombinante. Essas reações inespecíficas são resultados de interações fracas, e a ureia rompe essas ligações, permitindo apenas que os anticorpos de alta afinidade permaneçam ligados à proteína (81). Como resultado, vimos que cerca de $83 \%$ das amostras positivas para IgM possuíam alta avidez para a NS3 $3_{\mathrm{Hel}}$, enquanto que $11 \%$ eram de avidez media e $5 \%$ era de avidez baixa. Este resultado mostrou que de fato a positividade para IgM não se dava devido a reações inespecíficas e sim a uma alta especificidade para a proteína recombinante. Esta é uma característica muito interessante pois a relação especificidade está sempre associado aos anticorpos da classe $\operatorname{IgG}$, que também foi observado neste mesmo experimento.

Entretanto, nossa hipótese é refutada quando se utiliza as amostras dos pacientes com histórico de vacinação por mais de um ano. A quantidade de amostras positivas para IgM inviabiliza a ideia de que a NS3 $3_{\mathrm{Hel}}$ seria utilizada para o diagnóstico de fase aguda, mostrando uma inespecificidade substancial. Este fato, pode ser explicado talvez, devido aos produtos bacterianos residuais decorrentes da expressão do peptídeo, fato que poderia gerar uma grande quantidade de falsos positivos, uma vez que teríamos um grande quantidade de anticorpos contra os componentes bacterianos. Entretanto, devido à alta pureza da proteína ( $90 \%$ ) esta hipótese pode ser equivocada, para tentar responder a esta questão, era-se necessário utilizar um extrato de E. coli como controle do teste.

Em síntese, tentamos desenvolver um ensaio de ELISA que usa como antígeno de captura a $\mathrm{NS}_{\mathrm{Hel}}$ como forma de fazer o diagnóstico de fase aguda de Febre Amarela, e, apesar de apresentar inicialmente uma baixa sensibilidade, mostrou-se com uma especificidade interessante, não apresentando reações cruzadas com DENV e ZIKV. Porém, devido aos dados serem inconsistentes, decorrente a discordância dos resultados dos períodos de vacinação, trabalha-se com a premissa de que a NS3 Hel não seria um candidato viável para o diagnóstico de YFV. 


\section{CONCLUSÃO}

Como conclusão, o trabalho mostrou que a NS3 Hel apresenta uma maior detecção de anticorpos da classe IgM do que da classe IgG. Devido aos baixos níveis de sensibilidade a $\mathrm{NS}_{\text {Hel }}$ não seria uma boa candidata para ser usada para o diagnóstico de YFV. Sua importância poderia ser melhor explorada dentro de uma resposta celular, tornando-a um possível candidato vacinal. 


\section{REFERÊNCIAS}

1. Monath T. O., Vasconcelos P. F. C. Yellow fever. Journal of Clinical Virology (2015); 64: 160-173 (https://doi.org/10.1016/j.jcv.2014.08.030).

2. Gardner C. L., Ryman KD. Yellow Fever: A Reemerging Threat. Clinics in $\begin{array}{llll}\text { Laboratory } & \text { Medicine } & \text { 237-260 }\end{array}$ (https://doi.org/10.1016/j.cll.2010.01.001).

3. Figueiredo L. T. M., Fonseca B. A. L. Febre amarela. In: Tratado de infectologia. Editor Científico: Roberto Foccacia. São Paulo: Atheneu; (2015); pág. 455-464.

4. Lindenbach B. D., Rice C. M. Molecular biology of flaviviruses. Adv Virus Res 2003, 59: 23-61.

5. Lindenbach B. D., Murray C. L., Thiel H. J., Rice C. M. Flaviviridae. p. 712-746. In Knipe DM, Howley PM (ed.), Fields Virology. Vol 1, $6^{\text {th }}$ Ed. (2013) Lippincott Williams \& Wilkins, Philadelphia.

6. Beasley D. W. C., McAuley A. J., Bente D. A. Yellow fever vírus: genetic and phenotypic diversity and implications for detection, prevention and therapy. $\begin{array}{llll}\text { Antiviral } & \text { Research } & \text { (2015); } & \text { 115: }\end{array}$ (https://dx.doi.org/10.1016/j.antiviral.2014.12.010).

7. Quaresma J. Á., Pagliari C, Medeiros D. B., Duarte M. I., Vasconcelos P. F. C. Immunity and immune response, pathology and pathologic changes: progress and challenges in the immunopathology of yellow fever. Reviews in Medical Virology (2013); 23: 305-318. (doi: 10.1002/rmv.1752).

8. Querec T. D., Akondy R. S, Lee E. K., Cao W., Nakaya H. I., Teuwen D., Pirani A., Gernert K., Deng J., Marzolf B. et al.. Systems biology approach predicts immunogenicity of the yellow fever vaccine in humans. Nature Immunology (2009); 10: 116-125.

9. Gaucher D., Therrien R., Kattaf N., Angermann B. R., Boucher B., Filali-Mouhin A, Moser J. M., Mehta R. S., Drake D. R. et al.. Yellow fever vaccine induces integrated multilineage and polyfunctional imune responses. Journal of Experimental Medicine (2008); 205:3119-3131 (doi:10.1084/jem.20082292).

10. Querec T., Bennouna S., Alkan S., Laouar Y., Gorden K et al.. Yellow fever vacine YF-17D actives multiple dendritic cell subsets via TLR2, 7, 8, and 9 to stimulate polyvalent immunity. Journal of Experimental Medicina (2006); 203:413-424. (doi/10.1084/jem.20051720).

11. Simmons, M., Sun, P., \& Putnak, R. (2016). Recombinant dengue 2 Virus NS3 helicase protein enhances antibody and T-Cell response of purified inactivated vaccine. PLoS ONE, 11(4), 1-16. (https://doi.org/10.1371/journal.pone.0152811).

12. Prata A. Yellow Fever. Memórias do Instituto Oswaldo Cruz (2000); 95 (Suppl. I): $183-187$.

13. Fabro A. T., Engelman G. G., Ferreira N. N., Velloni J. M. F., Espósito D. L. A., da Fonseca B. A. L., Brunaldi M. O. Yellow Fever-Induced Acute Lung Injury. American Journal of Respiratory and Critical Care Medicine (2019). https://doi.org/10.1164/rccm.201711-2267IM.

14. Miller J. D., van der Most R. G., Akondy R. S., Glidewell J. T., Albott S. et al. Human Efecctor and Memory CD8+ T Cell Response to Smallpox and Yellow Fever Vaccines. Immunity (2008); 28: 710-722.

15. Barba-Spaeth G., Longman R. S., Albert M., Rice C. M. Live attenuated yellow fever 17D infects human DCs and allows for presentation of endogenous and 
recombinant $\mathrm{T}$ cell epitopes. Journal of Experimental Medicine (2005); 202: 1179-1184.

16. World Health Organization: Vaccine and vaccination against yellow fever, WHO position paper - June 2013. Weekly Epidemiological Report. No 27 (2013) 88: 269-284.

17. Pan American Health Organization. "Yellow fever outbreak in Paraguay." Boletim Epidemiológico. 2008; 27:1.

18. Kengsakul K., Sathirapongsasuti K., Punyagupta S. Fatal myeloencephalitis following yellow fever vaccination in a case with HIV infection. Journal of the Medical Association of Thailand (2002); 85: 131-134.

19. De Menezes M. R., da Luz F. L. M., Homma, A. (2015). Serious adverse events associated with yellow fever vaccine. Human Vaccines \& Immunotherapeutics, 11(9), 2183-2187. (https://doi.org/10.1080/21645515.2015.1022700).

20. Amanna, I. J., Slifka, M. K., National, O., \& Health, O. (2017). Questions regarding the safety and duration of immunity following live Yellow Fever vaccination, 15(12), 1519-1533. (https://doi.org/10.1080/14760584.2016. 1198259).

21. Galler, R., Pugachev, K. V., Santos, C. L. S., Ocran, S. W., Jabor, A. V., Rodrigues, S. G., Monath, T. P. (2001). Phenotypic and molecular analyses of yellow fever 17DD vaccine viruses associated with serious adverse events in Brazil. Virology, 290(2), 309-319. (https://doi.org/10.1006/viro.2001.1168).

22. Thomas RE. Yellow fever vaccine-associated viscerotropic disease: current perspectives. Drug Design, Development and Therapy, 2016:10 3345-3353.

23. Florczak-Wyspiańska, J., Nawotczyńska, E., \& Kozubski, W. (2017). Yellow fever vaccine-associated neurotropic disease (YEL-AND) - A case report. Neurologia i Neurochirurgia Polska, 51(1), 101-105. (https://doi.org/10.1016/j.pjnns.2016.09.002).

24. Cottin P, Niedrig M, Domingo C. Safety profile of the yellow fever vaccine Stamaril@: a 17-year review. Expert Rev Vaccines. 2013; 12(11):1351-1368.

25. Monath, T. P., Lee, C. K., Julander, J. G., Brown, A., Beasley, D. W., Watts, D. M., Trent, D. W. (2010). Inactivated yellow fever 17D vaccine: Development and nonclinical safety, immunogenicity and protective activity. Vaccine, 28(22), 3827-3840. (https://doi.org/10.1016/j.vaccine.2010.03.023).

26. Pereira, R. C., Silva, A. N. M. R., Souza, M. C. O., Silva, M. V., Neves, P. P. C. C., Silva, A. A. M. V., Caride, E. (2015). An inactivated yellow fever 17DD vaccine cultivated in Vero cell cultures. Vaccine, 33(35), 4261-4268. (https://doi.org/10.1016/j.vaccine.2015.03.077).

27. Gaspar, L. P., Mendes, Y. S., Yamamura, A. M. Y., Almeida, L. F. C., Caride, E., Gonçalves, R. B., Freire, M. S. (2008). Pressure-inactivated yellow fever 17DD virus: Implications for vaccine development. Journal of Virological Methods, 150(1-2), 57-62. (https://doi.org/10.1016/j.jviromet.2008.03.002).

28. Monath, T. P., Fowler, E., Johnson, C. T., Balser, J., Morin, M. J., Sisti, M., \& Trent, D. W. (2011). An Inactivated Cell-Culture Vaccine against Yellow Fever. New England Journal of Medicine, 364(14), 1326-1333. (https://doi.org/10.1056/NEJMoa1009303).

29. Petrovsky, N., Aguilar, J. C. (2004). Vaccine adjuvants: Current state and future trends. Immunology and Cell Biology, 82(5), 488-496. (https://doi.org/10.1111/j.0818-9641.2004.01272.x)

30. Schafer, B., Holzer, G., Joachimsthaler, A., Coulibaly, S., Schwendinger, M., Crowe, B. et al. (2011) Preclinical efficacy and safety of experimental vaccines 
based on non-replicating vaccinia vectors against yellow fever. PLoS One 6(9): e24505.

31. da Fonseca B. A., Pincus S., Shope R. E., Paoletti E., Mason P. W. Recombinant vaccinia viruses co-expressing dengue-1 glycoproteins prM and $\mathrm{E}$ induce neutralizing antibodies in mice. Vaccine. 1994;12(3):279-85.

32. De Paula S. O., Lima D. M., de Oliveira França R. F., Gomes-Ruiz A. C., da Fonseca B. A. A DNA vaccine candidate expressing dengue-3 virus prM and $\mathrm{E}$ proteins elicits neutralizing antibodies and protects mice against lethal challenge. Arch Virol. 2008;153(12):2215-23. (doi:10.1007/s00705-008-0250-3).

33. Lima D. M, de Paula S. O., França R. F., Palma P. V., Morais F. R., Gomes-Ruiz A. C., de Aquino M. T., da Fonseca B. A. A DNA vaccine candidate encoding the structural $\mathrm{prM} / \mathrm{E}$ proteins elicits a Strong immune response and protects mice against dengue-4 virus infection. Vaccine. 2011 Jan 17;29(4):831-8. (doi: 10.1016/j.vaccine.2010.10.078).

34. Lauretti F., Chattopadhyay A., de Oliveira França R. F., Castro-Jorge L., Rose J., Fonseca B. A. Recombinant vesicular stomatitis virus-based dengue- 2 vaccine candidate induces humoral response and protects mice against lethal infection. Human Vaccine \& Immunotherapeutics. 2016 Sep;12(9):2327-33. (doi:10.1080/21645515.2016.1183857).

35. Van Der Most, R. G., Harrington, L. E., Giuggio, V., Mahar, P. L., \& Ahmed, R. (2002). Yellow fever virus 17D envelope and NS3 proteins are major targets of the antiviral $\mathrm{T}$ cell response in mice. Virology, 296(1), 117-124. (https://doi.org/10.1006/viro.2002.1432).

36. Russell P. K., Nisalak A., Sukhavachna P., Vivona S. A plaque reduction test for dengue vírus neutralizing antibodies. Journal of Immunology (1967); 2: 285-290.

37. Schöberl, F., Csanadi, E., Eren, O., Dieterich, M., \& Kümpfel, T. (2017). NMOSD triggered by yellow fever vaccination - An unusual clinical presentation with segmental painful erythema. Multiple Sclerosis and Related Disorders, (2016), 11: 43-44. (https://doi.org/10.1016/j.msard.2016.11.009).

38. Martin M., Tsai T. F., Cropp C. B, et al. Multi-systemic illness in elderly recipients of yellow fever vaccine report of four cases. Lancet, 358 (2001), p. 98.

39. Fernando, P. (2003). Febre amarela Yellow fever. Revista Da Sociedade Brasileira de Medicina Tropical, 36(2), 275-293.

40. Haller A. A., Duke R. C., Kemmler C., Lauer G. M., Rodell T. C., Franzusoff A., King, T. H. (2006). Whole recombinant yeast-based immunotherapy induces potent $\mathrm{T}$ cell responses targeting HCV NS3 and Core proteins. Vaccine, 25(8), 1452-1463. (https://doi.org/10.1016/j.vaccine.2006.10.035).

41. Siconelli, M. J. L., Esposito, D. L. A., Morais, N. C., Ribeiro, J. M., Dias, M. A., Perles, L., Carvalho, A. A. B., Werther, K., Burger, K. P. and Fonseca, B. A. L. Yellow fever virus isolate JabSPM02 polyprotein gene, partial cds. GenBank: MF443185.1.

42. Mantel N., Aguirre M., Guilia S., Girerd-Chambaz Y., Colombani S., Moste C., Barban V. Standardized quantitative RT-PCR assays for quantitation of yellow fever and chimeric yellow fever-dengue vacines. Journal of Virological Methods (2008) 151: 40-46. (https://doi.org/10.1016/j.jviromet.2008.03.0260).

43. Parasuraman, S., Raveendran, R., \& Kesavan, R. (2010). Blood sample collection in small laboratory animals. Journal of pharmacology \& pharmacotherapeutics, 1(2), 87-93. (doi:10.4103/0976-500X.72350)

44. Monath T. P. Yellow fever vaccine: Expert Review of Vaccines (2005); 4: 553574. (https://doi.org/10.1586/14760584.4.4.553). 
45. Kao Y., Yu, C., Huang H., Wang W., Yang, M., Anderson, R., Wan S. Combination of Modified NS1 and NS3 as a Novel Vaccine Strategy against Dengue Virus Infection. (2019). (https://doi.org/10.4049/jimmunol.1900136)

46. James, E. A., Lafond, R. E., Gates, T. J., Mai, D. T., Malhotra, U., \& Kwok, W. W. (2013). Yellow Fever Vaccination Elicits Broad Functional CD4 ${ }^{+}$T Cell Responses That Recognize Structural and Nonstructural Proteins, 87(23), 1279412804. (https://doi.org/10.1128/JVI.01160-13.)

47. López L, Venteo A, Jiménez-Clavero MA, Carrasco JL, Cano MJ, Soria E, et al. Evaluation of the baculovirus and E. coli-expressed non-structural (NS) proteins of bluetongue virus (BTV) as antigen in na indirect or competition ELISA to differentiate infected from vaccinated animals. Microbial Cell Factories. 2006; 5 (Suppl 1):P59.

48. Simmons, C. P., Dong, T., Chau, N. V., Dung, N. T. P., Chau, T. N. B., Thao, L. T. T., Farrar, J. (2005). Early T-Cell Responses to Dengue Virus Epitopes in Vietnamese Adults with Secondary Dengue Virus Infections. Journal of Virology, 79(9), 5665 LP-5675. (https://doi.org/10.1128/JVI.79.9.5665 5675.2005.)

49. Spaulding, A. C., Kurane, I., Ennis, F. A., \& Rothman, A. L. (1999). Analysis of Murine CD8(+) T-Cell Clones Specific for the Dengue Virus NS3 Protein: Flavivirus Cross-Reactivity and Influence of Infecting Serotype. Journal of Virology, 73(1), 398 LP-403.

50. Weiskopf, D., Bangs, D. J., Sidney, J., Kolla, R. V., De Silva, A. D., de Silva, A. M., Sette, A. (2015). Dengue virus infection elicits highly polarized CX3CR1+ cytotoxic CD4+ T cells associated with protective immunity. Proceedings of the National Academy of Sciences of the United States of America, 112(31).

51. Reeves, P. M., Sluder, A. E., Paul, S. R., Scholzen, A., Kashiwagi, S., \& Poznansky, M. C. (2018). Application and utility of mass cytometry in vaccine development. The FASEB Journal, 32(1), 5-15. (https://doi.org/10.1096/fj.201700325R.)

52. Hung, C., Wozniak, K. L., \& Cole, G. T. (2016). Chapter 31 Flow Cytometric Analysis of Protective T-Cell Response Against Pulmonary Coccidioides Infection, 1403. (https://doi.org/10.1007/978-1-4939-3387-7.)

53. SAMBROOK, J.; RUSSELL, D. W. Molecular cloning: a laboratory manual. 3ed. Cold Spring Harbor, New York, 2001.

54. Domingo, C. (2018). Yellow fever in the diagnostics laboratory. Emerging Microbes \& Infections. (https://doi.org/10.1038/s41426-018-0128-8)

55. Levett, P. N., Sonnenberg, K., Sidaway, F., Shead, S., Niedrig, M., Steinhagen, K., Drebot, M. A. (2005). Use of Immunoglobulin G Avidity Assays for Differentiation of Primary from Previous Infections with West Nile Virus, 43(12), 5873-5875. (https://doi.org/10.1128/JCM.43.12.5873)

56. Structural features of Zika virus non-structural proteins 3 and -5 andits ind.pdf. (n.d.).

57. Kwallah, A., Inoue, S., Thairu-muigai, A. W., Kuttoh, N., Morita, K., \& Mwau, M. (2015). Seroprevalence of Yellow Fever Virus in Selected Health Facilities in Western Kenya from 2010 to 2012, (16), 230-234. (https://doi.org/10.7883/yoken.JJID.2014.288)

58. Ange, I., Ramı, R., Alvarez, M., \& Beatriz, A. (n.d.). Recombinant dengue 2 virus NS3 protein conserves structural antigenic and immunological properties relevant for dengue vaccine design. https://doi.org/10.1007/s11262-014-1087-3 
59. Putnak, J. R., \& Schlesinger, J. J. (1990). Protection of mice against yellow fever virus encephalitis by immunization with a vaccinia virus recombinant encoding the yellow fever virus non-structural proteins NS1, NS2a and NS2b, 3, 16971702.

60. Prospects for a virus non-structural protein as a subunit vaccine.pdf. (n.d.).

61. Xi, Y., Whittaker, K. (2017). Prokaryotic Expression of Hepatitis C Virus-NS3 Protein and Preparation of a Monoclonal Antibody, 36(6), 251-258. (https://doi.org/10.1089/mab.2017.0033)

62. Tacken, M. G. J., Daus, F. J., Feenstra, F., Gennip, R. G. P. Van, \& Rijn, P. A. Van. (2015). Development of a competitive ELISA for NS3 antibodies as DIVA test accompanying the novel Disabled Infectious Single Animal (DISA) vaccine for Bluetongue. $\quad$ Vaccine, 33(42), 5539-5545. (https://doi.org/10.1016/j.vaccine.2015.09.020)

63. Moreland, N. J., Tay, M. Y. F., Lim, E., Rathore, A. P. S., Lim, A. P. C., Hanson, B. J., Vasudevan, S. G. (2012). Monoclonal antibodies against dengue NS2B and NS3 proteins for the study of protein interactions in the flaviviral replication complex. Journal of Virological Methods, 179(1), 97-103. (https://doi.org/10.1016/j.jviromet.2011.10.006)

64. Duangchinda, T., Dejnirattisai, W., Vasanawathana, S., Limpitikul, W., Tangthawornchaikul, N., Malasit, P., Screaton, G. (2010). Immunodominant Tcell responses to dengue virus NS3 are associated with DHF, 107(39), 1-6. (https://doi.org/10.1073/pnas.1010867107)

65. Luce, C., Gadia, B., Manirakiza, A., Tekpa, G., Konamna, X., Vickos, U., \& Nakoune, E. (2017). Identification of pathogens for differential diagnosis of fever with jaundice in the Central African Republic: a retrospective assessment , 2008 - 2010, 1-5. (https://doi.org/10.1186/s12879-017-2840-8)

66. Lanciotti, R. S., Kosoy, O. L., Laven, J. J., Velez, J. O., Lambert, A. J., Johnson, A. J., Duffy, M. R. (2008). Genetic and Serologic Properties of Zika Virus Associated with an Epidemic, Yap State, 14(8). (https://doi.org/10.3201/eid1408.080287)

67. Saron, W. A. A., Rathore, A. P. S., Ting, L., Ooi, E. E., Low, J., Abraham, S. N., \& John, A. L. S. (2018). Flavivirus serocomplex cross-reactive immunity is protective by activating heterologous memory CD4 T cells, (July), 1-14.

68. Mackay, D. K. J., Forsyth, M. A., Davies, P. R., Belsham, G. J., Flint, M., \& Ryan, M. D. (1998). Differentiating infection from vaccination in foot-and-mouth disease using a panel of recombinant, non-structural proteins in ELISA, 16(5), 446-459.

69. Fob, I. D. B. (2013). Differential Targeting of Viral Components by CD4 ${ }^{+}$versus $\mathrm{CD}^{+} \mathrm{T}$ Lymphocytes in Dengue Virus Infection, 87(5), 2693-2706. (https://doi.org/10.1128/JVI.02675-12)

70. Ravichandran, S., Hahn, M., Belaunzarán-zamudio, P. F., Ramos-castañeda, J., Nájera-cancino, G., Caballero-sosa, S., Khurana, S. (2019). serodiagnostics and disease outcome. Nature Communications, 1-14. (https://doi.org/10.1038/s41467-019-09914-3)

71. Diagnostic application of recombinant non-structural protein $3 \mathrm{~A}$ to detect antibodies induced by foot-and-mouth disease virus infection.pdf. (n.d.). 
72. Ding, X., Li, X., Deng, Y., Guo, Y., Hao, W., \& Che, X. (2014). Development of a Double Antibody Sandwich ELISA for West Nile Virus Detection Using Monoclonal Antibodies against Non-Structural Protein 1, 9(10). (https://doi.org/10.1371/journal.pone.0108623)

73. Fu, Y., Li, P., Cao, Y., Wang, N., Sun, P., Shi, Q., Liu, Z. (2017). Development of a Blocking ELISA Using a Monoclonal Antibody to a Dominant Epitope in Non-Structural Protein 3A of Foot-and- Mouth Disease Virus, as a Matching Test for a Negative-Marker Vaccine. (https://doi.org/10.1371/journal.pone.0170560)

74. Castellanos, J. E. (2008). Dengue-yellow fever sera cross-reactivity; challenges for diagnosis, 10(2), 299-307.

75. Sharma, G. K., Mohapatra, J. K., Mahajan, S., Matura, R., Subramaniam, S., \& Pattnaik, B. (2014). Comparative evaluation of non-structural protein-antibody detecting ELISAs for foot-and-mouth disease sero-surveillance under intensive vaccination. Journal of Virological Methods, 207, 22-28. (https://doi.org/10.1016/j.jviromet.2014.06.022).

76. Maruyama, S. R., Castro-jorge, L. A., Marcos, J., Ribeiro, C., Gardinassi, L. G., Garcia, G. R., Miranda-santos, I. K. F. De. (2014). Characterisation of divergent flavivirus NS3 and NS5 protein sequences detected in Rhipicephalus microplus ticks from Brazil, 109 (February), 38-50. (https://doi.org/10.1590/00740276130166).

77. Bozzacco, L., Yi, Z., Andreo, U., Conklin, C. R., Li, M. M. H., Rice, C. M., \& Macdonald, M. R. (2016). Chaperone-Assisted Protein Folding Is Critical for Yellow Fever Virus NS3/4A Cleavage and Replication, 90(6), 3212-3228. (https://doi.org/10.1128/JVI.03077-15).

78. Toxocara, I. (2016). Kinetics and avidity of anti- Toxocara antibodies (IgG ) in rabbits experimentally infected with Toxocara canis, 2961, 99-104.

79. Narayan, R., Raja, S., \& Palani, G. (2020). A novel indirect ELISA for diagnosis of dengue fever Methods: Results: Material \& Methods, 5, 1-6.

80. Nile, W. (2018). Laboratory Diagnosis of Yellow Fever Virus infection Laboratory testing, (September), 1-8.

81. Wang Q., Lei Y., Lu X., Wang G., Du Q., Guo X., et al. (2019) Urea-mediated dissociation alleviate the false-positive Treponema pallidum-specific antibodies detected by ELISA. PLoS ONE 14(3): e0212893. (https://doi.org/10.1371/journal.pone.0212893).

82. Tsai, W., Youn, H., Tyson, J., Brites, C., Tsai, J., Pedroso, C., Wang, W. (2018). Use of Urea Wash ELISA to Distinguish Zika and Dengue Virus Infections. Emerging Infectious Diseases, 24(7), 1355-1359. (https://dx.doi.org/10.3201/eid2407.171170).

83. Azevedo, R. S. S., Cruz, A. C. R., Nunes, B. T. D., Quieroz, A. L. N., Oliveira, R. S., Medeiros, D. B. A., Rodrigues, D. S. G., Silva, E. V. P., Pantoja, J. A. S., Massafra, J. M. V., Santos, M., Silva, S. P., Lemos, P. S., Santos, A. C. M., Vasconcelos, H. B., Lima, J. A., Rodrigues, S. G., Tesh, R. B., Nunes, M. R. T. and Vasconcelos, P. F. C. Zika virus strain BeH819966 polyprotein gene, complete cds. GenBank: KU365779.1

84. Blom, N., Sicheritz-Pontén, T., Gupta, R., Gammeltoft, S. and Brunak, S. (2004), Prediction of post-translational glycosylation and phosphorylation of proteins 
from the amino acid sequence. Proteomics, 4: 1633-1649. (doi:10.1002/pmic.200300771)

85. Caroline, N., Clara, A., Vicente, A., Paula, D., Eduardo, J., \& Sérgio, C. (2019). International Journal of Infectious Diseases Evaluation of serological crossreactivity between yellow fever and other flaviviruses. International Journal of Infectious Diseases, 81, 4-5. (https://doi.org/10.1016/j.ijid.2019.01.023)

86. Ricciardi-jorge, T., Juliano, B., Koishi, A., Zanl, C., \& Luiza, A. (2017). Development of a quantitative immunosorbent assay for early detection of yellow fever virus infection, (November), 1-9. (https://doi.org/10.1038/s41598017-16231-6)

87. dos Santos, C. N., Post, P. R., Carvalho, R., Ferreira, I. I., Rice, C. M. and Galler, R. Yellow fever virus vaccine strain 17DD, complete genome. GenBank: U17066.1.

88. Altman, D. G.; Bland, J. M. Diagnostic tests 3: Receiver operating characteristic plots. British Medical Journal, v.309, n. 6948, p. 188, July, 1994. 
ANEXO 
Anexo A: Certificado de análise da expressão e purificação da NS3Hel pela empresa GenScript

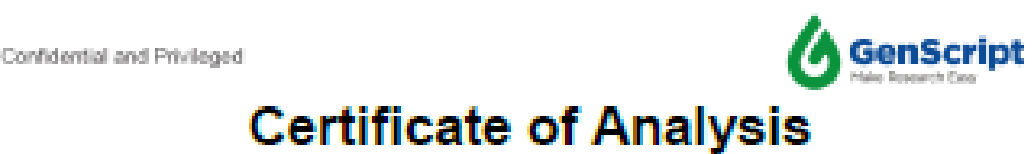

$\begin{array}{ll}\text { Order Number: } & \text { U1508ED020-5 } \\ \text { Protein Name: } & \text { Protein } 1 \\ \text { Shipping Condition: } & \text { Dry loe } \\ \text { Lot Number: } & \text { U1506ED020-5/P3EF001 }\end{array}$

\begin{tabular}{|c|c|}
\hline Codon Optimization: & Yes \\
\hline $\begin{array}{l}\text { Expression System \& } \\
\text { Vector: }\end{array}$ & Ecoli, Expression Vector pET30a \\
\hline $\begin{array}{l}\text { Expression } \\
\text { Optimization: }\end{array}$ & Yes \\
\hline Expression Scale: & $1 \mathrm{LTB}$ culture \\
\hline Tag Removal: & No \\
\hline Purification: & $\begin{array}{l}\text { Protein was obtained from inclusion bodies, one-step purification by Ni } \\
\text { column }\end{array}$ \\
\hline Package: & $10.80 \mathrm{mg} .4 .00 \mathrm{~m} /$ tube, 10 tubes \\
\hline Concentration: & $\begin{array}{l}0.27 \mathrm{mg} / \mathrm{ml} \text {, determined by Bradford protein assay with BSA as a } \\
\text { standard (ThermoFisher, Cat. No. 23236) }\end{array}$ \\
\hline Purity: & $\begin{array}{l}\text { About } 90 \% \text {, estimated by densitometric analysis of the Coomassie } \\
\text { Blue-stained SDS-PAGE gel under reducing condition }\end{array}$ \\
\hline Endotoxin Level: & 7.3 EU/mg (LAL Endotoxin Assay Kit, GenScript, Cat.No.L00350) \\
\hline Sterility: & Steriized via a $0.22 \mu \mathrm{m}$ filter and packaged aseptically \\
\hline $\begin{array}{l}\text { Two cycles of freeze- } \\
\text { thaw testing: }\end{array}$ & $\begin{array}{l}\text { No visible precipitation was observed (Referring to appendix Freeze- } \\
\text { Thaw Testing) }\end{array}$ \\
\hline Storage and Handling: & $\begin{array}{l}\text { Store at }-80^{\circ} \mathrm{C} \text {. Aliquots should be stored at the same temperature after } \\
\text { first use to avoid multiple freeze-thaws }\end{array}$ \\
\hline Storage Buffer: & PBS, $10 \%$ Glycerol, 0.5 M L-Arginine, pH 7.4 \\
\hline $\begin{array}{l}\text { icript USA, Inc. } \\
\text { sript } 860 \text { Cantannial Awe. Pisco }\end{array}$ & away, NJ 08854 \\
\hline
\end{tabular}


SDS-PAGE \& Western blot Analysis:
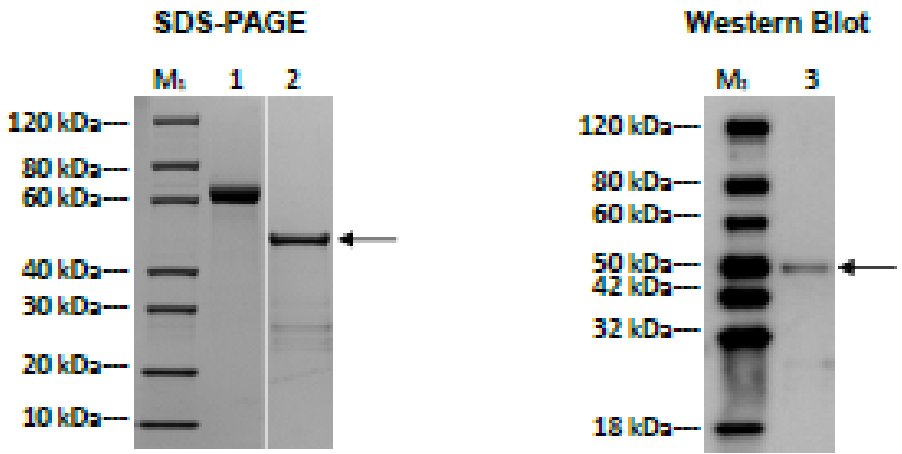

Fig-1 SDS-PAGE and Western blot analysis of Protein 1 Lane $\mathrm{M}_{1}$ - Protein Marker, GenScript, Cat. No. M00516 Lane $M_{2}$ : Protein Marker, GenScript, Cat. No. M00521 Lane 1: BSA $(2.00 \mu \mathrm{g})$

Lane 2: Protein 1 (Reducing condition, $2.00 \mu g$ )

Lane 3: Protein 1 (Reducing condition)

Primary antibody. Mouse-anti-His mAb (GenScript, Cat.No. A00186)

Quantification--BSA Standard Curve:

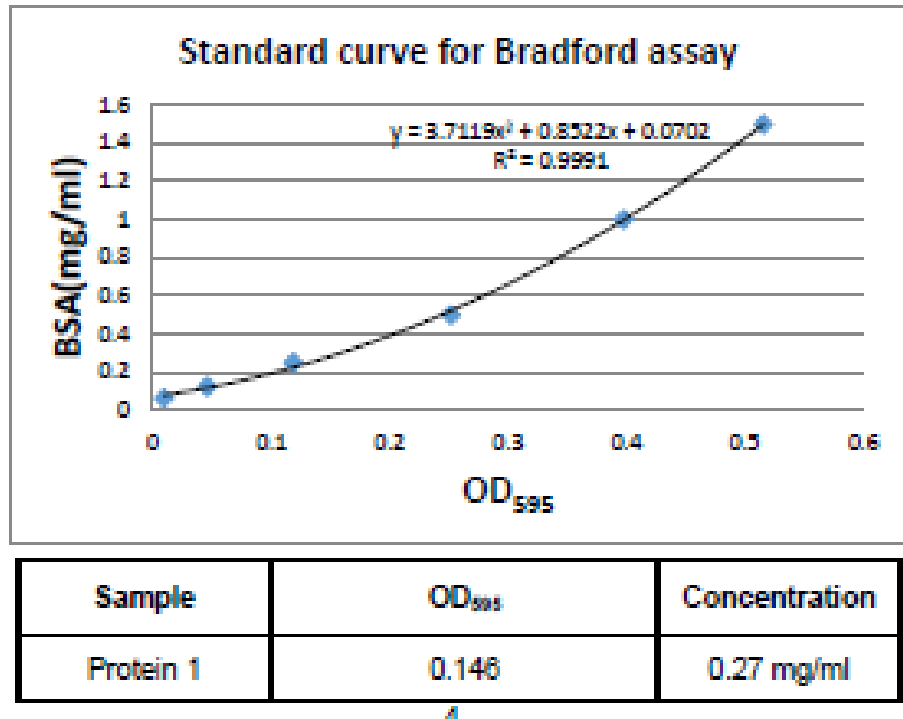

GenScript USA, Inc. 


\section{Packing List of U1506ED020-5}

Protein (Shipping Condition: $-80^{\circ} \mathrm{C}$ Dry lce, Store at $-80^{\circ} \mathrm{C}$ )

Protein name: Protein 1

Fused with: His tag

Concentration: $0.27 \mathrm{mg} / \mathrm{ml}$

Purity: $\sim 90 \%$

Endotoxin Level: 7.3 EU/mg

Buffer: PBS, 10\% Glycerd, 0.5 M L-Arginine, pH 7.4

Lot: U1508ED020-5/P3EF001

Total: $10.80 \mathrm{mg} .4 .00 \mathrm{~m} / \mathrm{tube}, 10$ tubes

\section{Packing List of U1506ED020-3}

Plasmid (Shipping Condition: Room Temperature, Store at $-20^{\circ} \mathrm{C}$ )

U1506ED020-1 (Protein 1) in pET-30a(+), $4.00 \mu g, 1$ tube, Lot: U5549ED030-2/M96306

Certified by:

Date: $06 / 27 / 2019$ 
Anexo B: Alinhamento das sequências da NS3 $3_{\mathrm{Hel}}$ YFV x DENV-2

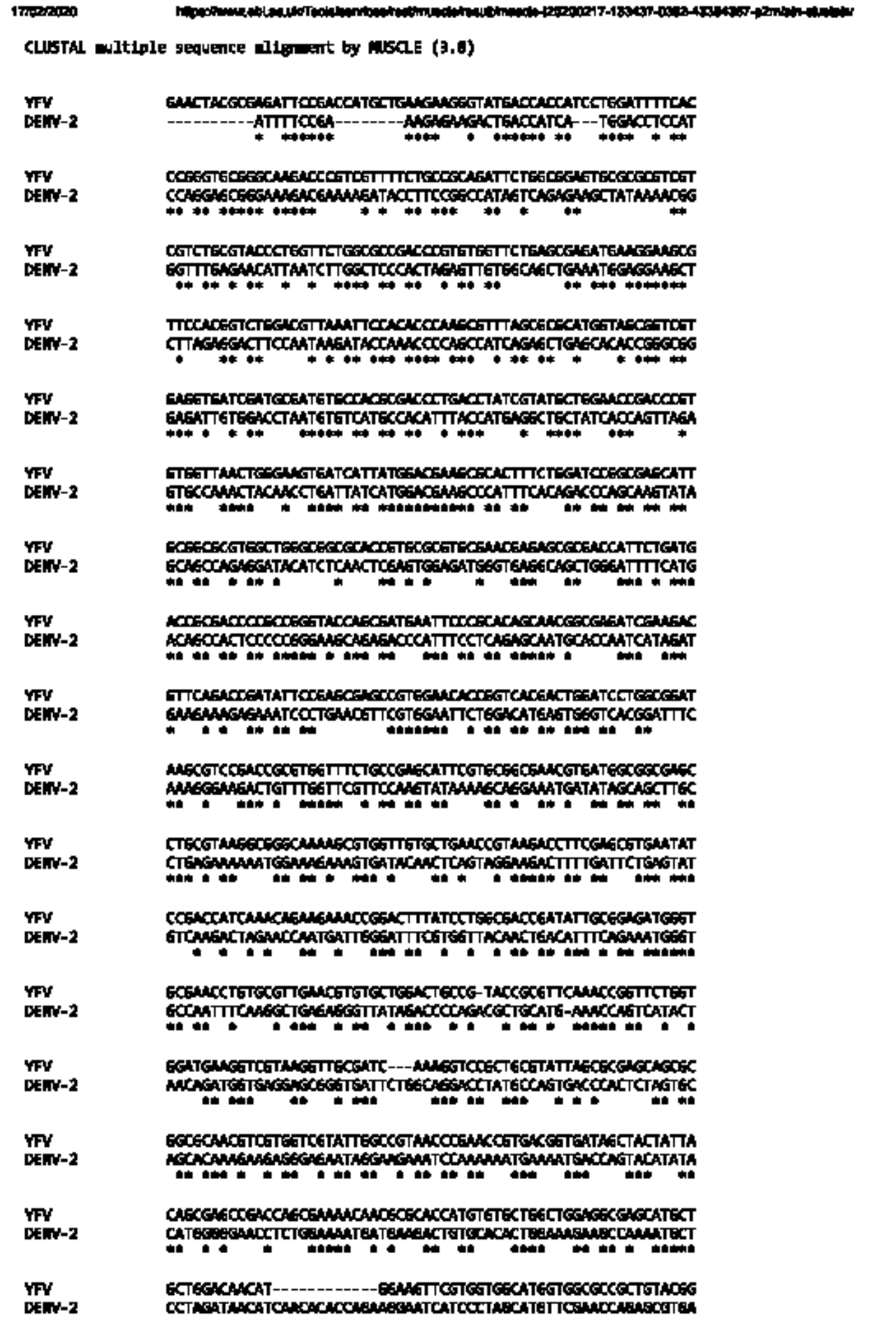


17imangen

YFY

DEIT-2

YFY

Deini-2

YFY

DEMr-2

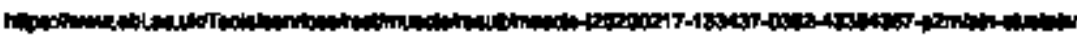

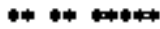

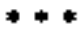

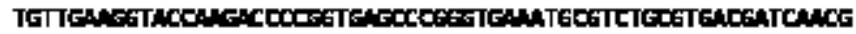

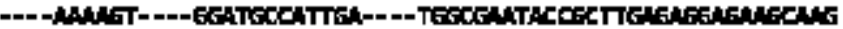

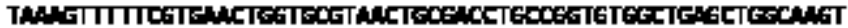

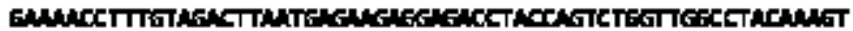

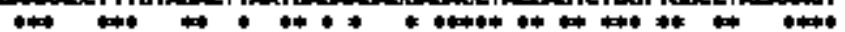

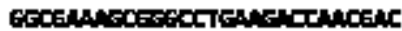

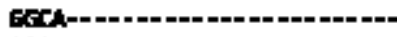

+4) 
Anexo C: Alinhamento das sequencias da NS3 Hel YFV x ZIKV (BeH819966 - Instituto Evandro Chagas, Belém, Para, Brasil)

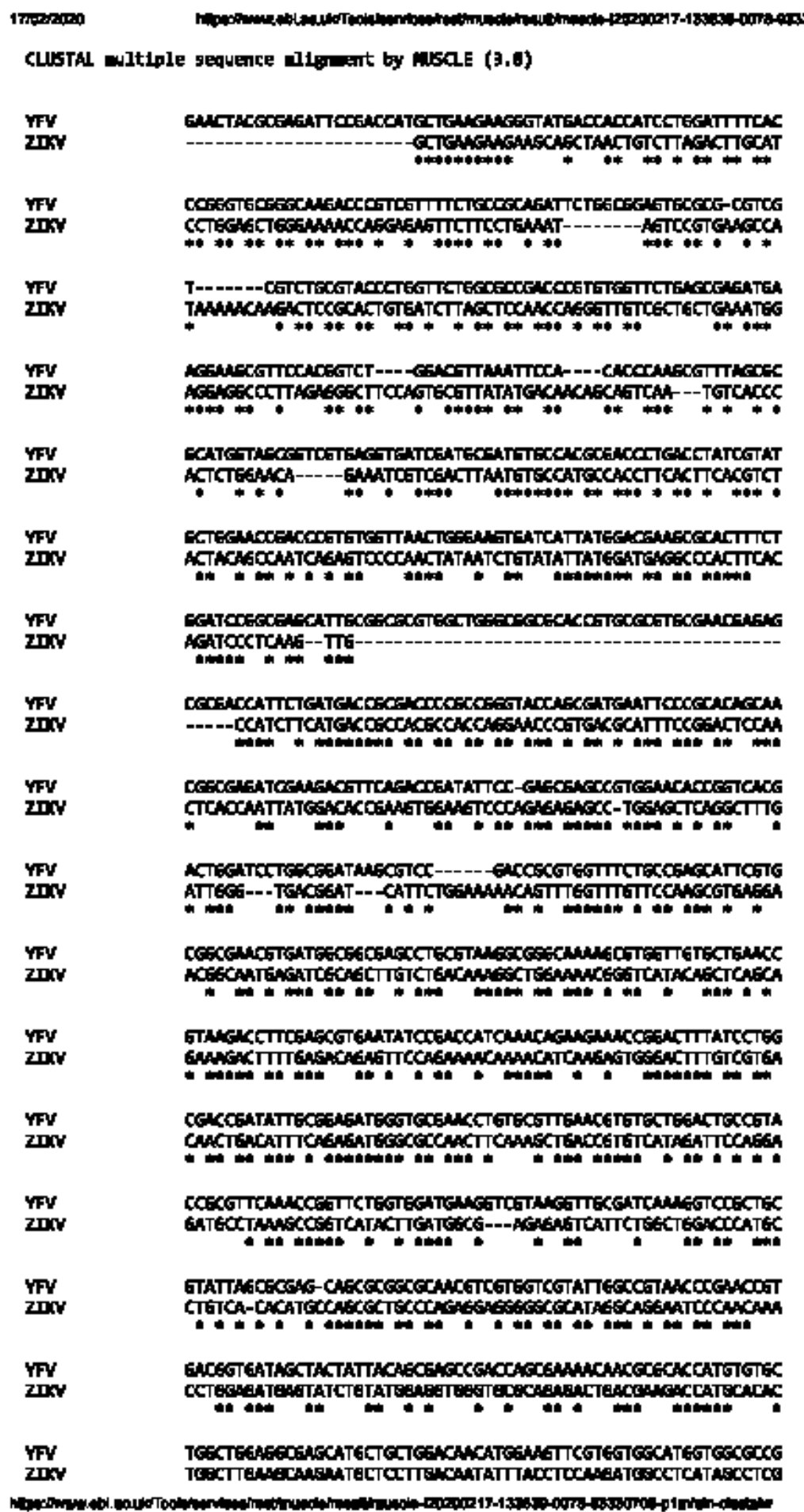


1 timengen

YFY

ziny

YFY

znxy

YFY

znxy

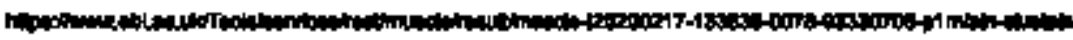

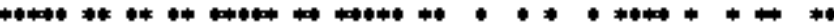

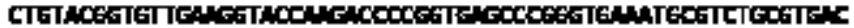

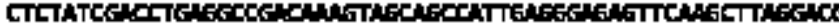

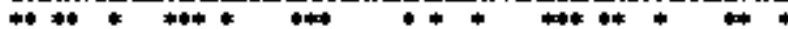

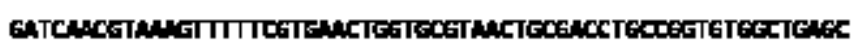

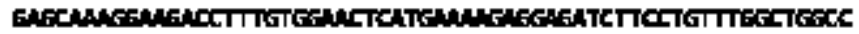

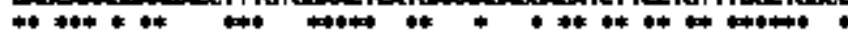

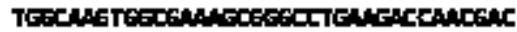

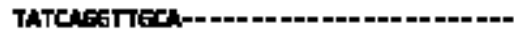

$* * 0 * * *$ 
Anexo D: Parecer do comitê de ética no uso das amostras humanas

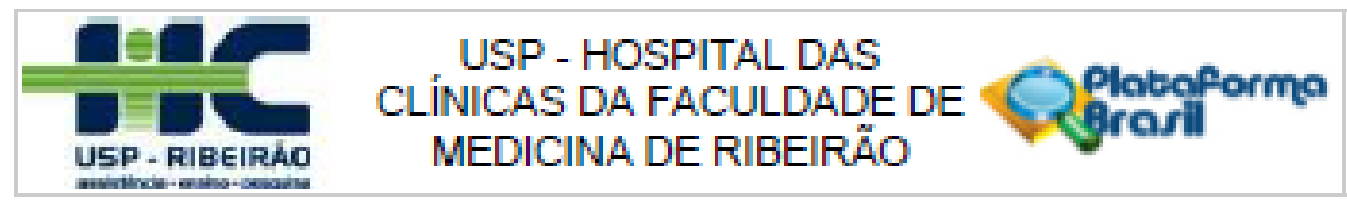

\section{PARECER CONSUBSTANCIADO DO CEP}

\section{DADOS DO PRONETO DE PESQUISA}

Titulo da Pocquica: Estudo dos eventos virologicos e Imunologicos em humanos apos imunizaç5́o com a vacina para Febre Amarela YF-17DD: andise da posalvel capacidade de proteçblo cruzads envolvendo infecçles heterdiogas.

Pocqulcador: BEATRZ DOS SANTOS RIBEIRO

Area Tematioa:

Vertso: 2

CAAE: 97416718.8 .0000 .5440

Inctitulģso Proponento: Faculdsde de Medicina de Ribeirdo Freto da Univeraldade de alo Paulo

Patroolnador Prinolpal: Financiamento Proprio

\section{DADOS DO PARECER}

Numero do Pareoer: 2.914.563

Aprecentagso do Projeto:

A doença causada peis infeç̧\$ిం do virus zika tomou proporçbes devastadoras, principaimente devido a sua capacidade de causar anormalidades fetals, como a microcefalls e complicaçles neuroibglcas como a doença de Gullilan-Barre.

Uma outra arbovirose que permanece sendo um serio probiema em areas endemicas da Africa tropical e subtropical e tambem na America do aul, incluindo o Brasll, e a febre amarela. No entanto, uma vacina segurs e efetva desenvolvida por Max Theiler e colaboradores encontra-se disponivel ha mals de 65 anos e vem garantindo uma proteç5o acima de $98 \%$ a seus receptores.

A vacinaçlo com a cepa $Y=1700$ leva a produç5o de anticonpos neutralizantes que conferem ata proteçlo contra infecçbles com o virus da febre amarela e um importante aspecto relacionado aos favivirus em gera! e a hipotese relacionada a capacidade dos mesmos em conferir proteçśo Imunologica cruzada apoa Infecçles heterologas.

Desaa maneira, a propoata geral deste projeto e anallas se a imunizaçlo com a vacina YF-17DD contra febre amarela leva a ocorrencia de eventos imunologicos que culminem na proteçlo contra uma infecçblo pelo virus zika, pelo menoa noa primeiros meses apos a vacinaç5o.

Objattvo da Pocquica:

O objettivo geral deste projeto e avalar se os eventos imunologicos desencadeados apos a imunizaç̧o de humanos com a vacina $Y F-17 D D$ contra febre amarela slo capazea de prevenir ou

Endenepa: cavpus uNvensmkeic

Balrna: Monte Rielane.

UF: BP Munkiplo Rosenao paeto

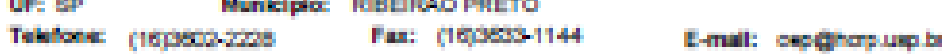




USP - HOSPITAL DAS
USP-RIBINICAS DA FACULDADE DE
MEDICINA DE RIBEIRÃO

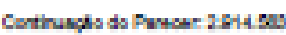

modular o processo de infecç5o ou replicaçso do virus zka.

Obietvos especincos

1. Detectar, peia tecrica de ensalo de neutralizaço viral, anticorpos neutralzantes ant-YF de indlviduos vacinados com a vacina YF-17DO;

2. Avalar, pela tecnica de ensaio de neutralzaç5o viral, a proteç5o cruzada dos anticorpos neutralzantes anthrF contra o virus zika.

Arallsgso doc Rileoos o Benefloloc:

Conatam no projeto $=$ TCLE

Comentarioc o Conclderapoec cobre a Pocquica:

O projeto e TCLE foram adequados seguindo as supestbes.

Conclderagoec cobre oc Termoc de aprecentaģso obrigatorla:

Conatam da submisabo e foram adequados conforme superido.

Recomendaģoec:

NSo ae aplea.

Concluebec ou Pendb́nolsc o Lleta de Insdequspoec:

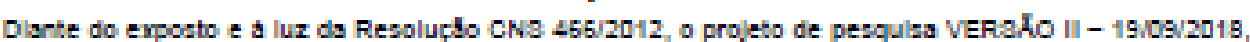
asaim como o Termo de Consentimento Livre e Eaciarecido VERaÁ II - 19V09/2018, podem ser enquadrados na categoria APROVADO.

Conclderagoec Flnale a orttorio do CEP:

Projeto Aprovado: Tendo em vista a leglalaçjo vigente, devem ser encaminhados ao CEP, relatorios parclala anus/s referentes 90 andamento da pesquisa e relaterio inal ao termino do trabalho. Gualquer modifcaçbo do projeto original deve ser apresentada a eate CEP em nova vers5o, de forma objetha e com Justulicativas, para nova apredaç5o.

Ecte pareoer fol olaborado becsado noc dooumentoc abalwo relsolonadoc:

\begin{tabular}{|c|c|c|c|c|}
\hline Tlpo Documento & Avquivo & Fostapem & Autor & उhusça \\
\hline $\begin{array}{l}\text { Informagdes Easicas } \\
\text { do Proleto }\end{array}$ & $\begin{array}{l}\text { PB_INFORMAÇCEB_BASICA3_DO_P } \\
\text { ROJETO_958907 pdf }\end{array}$ & $\begin{array}{c}19 / 03 / 2018 \\
21-36: 42\end{array}$ & & Acelto \\
\hline Outros & C.ARTA_RESPOSTA dOCX & $\begin{array}{c}1903 / 2018 \\
21 / 36,07\end{array}$ & $\begin{array}{l}\text { BEATRR DOB } \\
\text { SANTOS RIEEIRO }\end{array}$ & Acelto \\
\hline
\end{tabular}

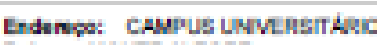

Balma: MoNTE kLEafi:

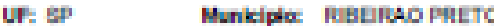

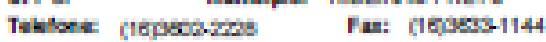

CEP: 14.045000

E-mal: ceseharsup br 


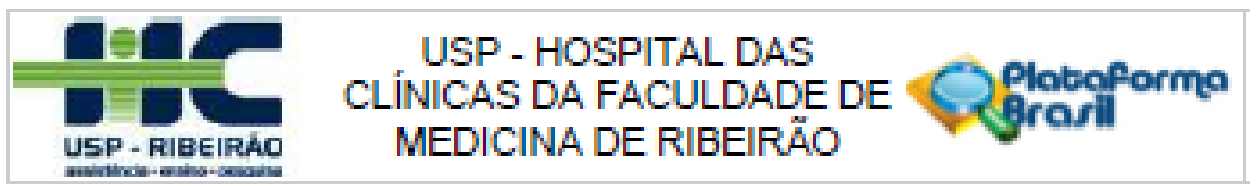

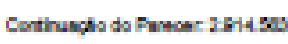

\begin{tabular}{|c|c|c|c|c|}
\hline $\begin{array}{l}\text { TCLE / Termos de } \\
\text { Assentimento / } \\
\text { Justificativa de } \\
\text { Augfincls }\end{array}$ & Termo_Consentimento_Bla.doc & $\begin{array}{c}19 / 09 / 2018 \\
21-3550\end{array}$ & $\begin{array}{l}\text { BEATRZ DOB } \\
\text { BANTOS RIEEIRO }\end{array}$ & Acelto \\
\hline $\begin{array}{l}\text { Proleto Detahado / } \\
\text { Brochura } \\
\text { Inveztspador }\end{array}$ & PRO.ETO_DETALHADO.doC & $\begin{array}{c}19 / 09 / 2018 \\
21: 35: 38\end{array}$ & $\begin{array}{l}\text { BEATRZ DOB } \\
\text { BANTOS RIEEIRO }\end{array}$ & Aceito \\
\hline Outros & HFOO12.pd & $\begin{array}{c}29 / 08 / 2018 \\
11: 19: 36 \\
\end{array}$ & \begin{tabular}{|l} 
BEATRE DOS \\
BANTOS RI BEIRO \\
\end{tabular} & Acelto \\
\hline Cronograma & CRONOGRAMA DOCX & $\begin{array}{c}29 / 08 / 2018 \\
1101: 58 \\
\end{array}$ & $\begin{array}{l}\text { BEATRZ DOS } \\
\text { RANTOQ RIAEIRQ }\end{array}$ & Acelto \\
\hline Folha de Rosto & HFod13.pdt & $\begin{array}{c}28 / 08 / 2018 \\
09: 47: 27\end{array}$ & $\begin{array}{l}\text { BEATRZ DOB } \\
\text { BANTOS RUEEIRO }\end{array}$ & Aceito \\
\hline
\end{tabular}

situsgso do Parooer:

Aprovado

Nooeccita Apreolagso da CONEP:

NSo

RIEEIRAO FRETO, 25 de Qetembro de 2018

Acclnado por:

MARCIA GUIUARAES VILLANOVA

[Coordenador[a]]

Endenpa: CANPUS LNVERSTReO

Ealma: MONTE RLEARE.

CEP: 14.045000

UF: BP Munkipio ReBenao pheto

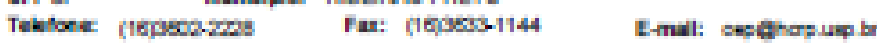


